\title{
External-Cost Estimation of Electricity Generation in G20 Countries: Case Study Using a Global Life-Cycle Impact-Assessment Method
}

\author{
Selim Karkour*, Yuki Ichisugi, Amila Abeynayaka@ and Norihiro Itsubo \\ Graduate School of Environmental Studies, Tokyo City University, Yokohama 224-8551, Japan; \\ g1793102@tcu.ac.jp (Y.I.); g1993101@tcu.ac.jp (A.A.); itsubo-n@tcu.ac.jp (N.I.) \\ * Correspondence: g1893103@tcu.ac.jp
}

Received: 9 February 2020; Accepted: 2 March 2020; Published: 5 March 2020

\begin{abstract}
The external costs derived from the environmental impacts of electricity generation can be significant and should not be underrated, as their consideration can be useful to establish a ranking between different electricity generation sources to inform decision-makers. The aim of this research is to transparently evaluate the recent external cost of electricity generation in G20 countries using a global life-cycle impact-assessment (LCIA) method: life cycle impact assessment method based on endpoint modeling (LIME3). The weighting factors developed in the LIME3 method for each G20 country enable one to convert the different environmental impacts (not only climate change and air pollution) resulting from the emissions and resources consumption during the full lifecycle of electricity generation - from resource extraction to electricity generation-into a monetary value. Moreover, in LIME3, not only the weighting factors are developed for each G20 country but also all the impact categories. Using this method, it was possible to determine accurately which resources or emission had an environmental impact in each country. This study shows that the countries relying heavily on coal, such as India $(0.172 \$ / \mathrm{kWh})$ or Indonesia $(0.135 \$ / \mathrm{kWh})$ have the highest external costs inside the G20, with air pollution and climate accounting together for more than $80 \%$ of the costs. In these two countries, the ratio of the external cost/market price was the highest in the G20, at 2.3 and 1.7 , respectively. On the other hand, countries with a higher reliance on renewable energies, such as Canada $(0.008 \$ / \mathrm{kWh})$ or Brazil $(0.012 \$ / \mathrm{kWh})$ have lower induced costs. When comparing with the market price, it has to be noted also that for instance Canada is able to generate cheap electricity with a low-external cost. For most of the other G20 countries, this cost was estimated at between about $0.020 \$$ and $0.040 \$ / \mathrm{kWh}$. By estimating the external cost of each electricity generation technology available in each G20 country, this study also highlighted that sometimes the external cost of the electricity generated from one specific technology can be significant even when using renewables due to resource scarcity—for example, the $0.068 \$ / \mathrm{kWh}$ of electricity generated from hydropower in India. This information, missing from most previous studies, should not be omitted by decision makers when considering which type of electricity generation source to prioritize.
\end{abstract}

Keywords: electricity generation; external cost; life-cycle assessment; life-cycle impact assessment; fossil fuels; renewables; G20; newly industrialized countries

\section{Introduction}

The management of energy systems has become a progressively more important topic in recent years. Under the growing concern of climate change consequences, decision makers are facing several types of challenges (economic, environmental, and social) to prioritize one source over another. 
Electricity generation reached 26,615 TWh in 2018 [1], increasing by 3.7\% from the previous year, as shown in Figure 1, with around 85\% of consumption occurring in G20 countries [2] (Figure A1). About $65 \%$ of global electricity is generated from fossil fuels (coal, natural gas, and oil). As a result, combined with heat generation, the electricity sector globally represents $42 \%$ of total annual $\mathrm{CO}_{2}$ emissions, with China (34\%), the USA (13\%), and India ( $8 \%$ ) accounting for the highest share [3]. The heavy use of fossil-based sources, especially coal, also has an impact on airborne-substance emissions and on mineral-resource consumption. Regarding air pollution in India, the public-electricity and heat-production sector was responsible for $44 \%$ and $65 \%$ of total $\mathrm{NOx}$ and $\mathrm{SO}_{2}$ emissions in 2012, respectively [4]. For resource consumption, coal consumption in China and India has multiplied by 3.8 and 4.5 times since 1990 to reach 3770 and $982 \mathrm{Mt}$ in 2018, respectively [5]. Globally, the consumption of natural gas has been also on the rise, especially in Asia, where some policies aim at replacing coal with natural gas, such as in China. The electricity sector is now responsible for $21 \%$ of the Chinese natural-gas consumption, and the sector was responsible for about $50 \%$ of the global annual consumption growth between 2011 and 2017 [6]. Only the generation of electricity by oil has been declining in recent years [7], especially in Japan and Korea, with the switch from oil to natural gas. One of the reasons is its emissions, especially in sulfur dioxide, which were estimated to be the highest among all power sources [8].

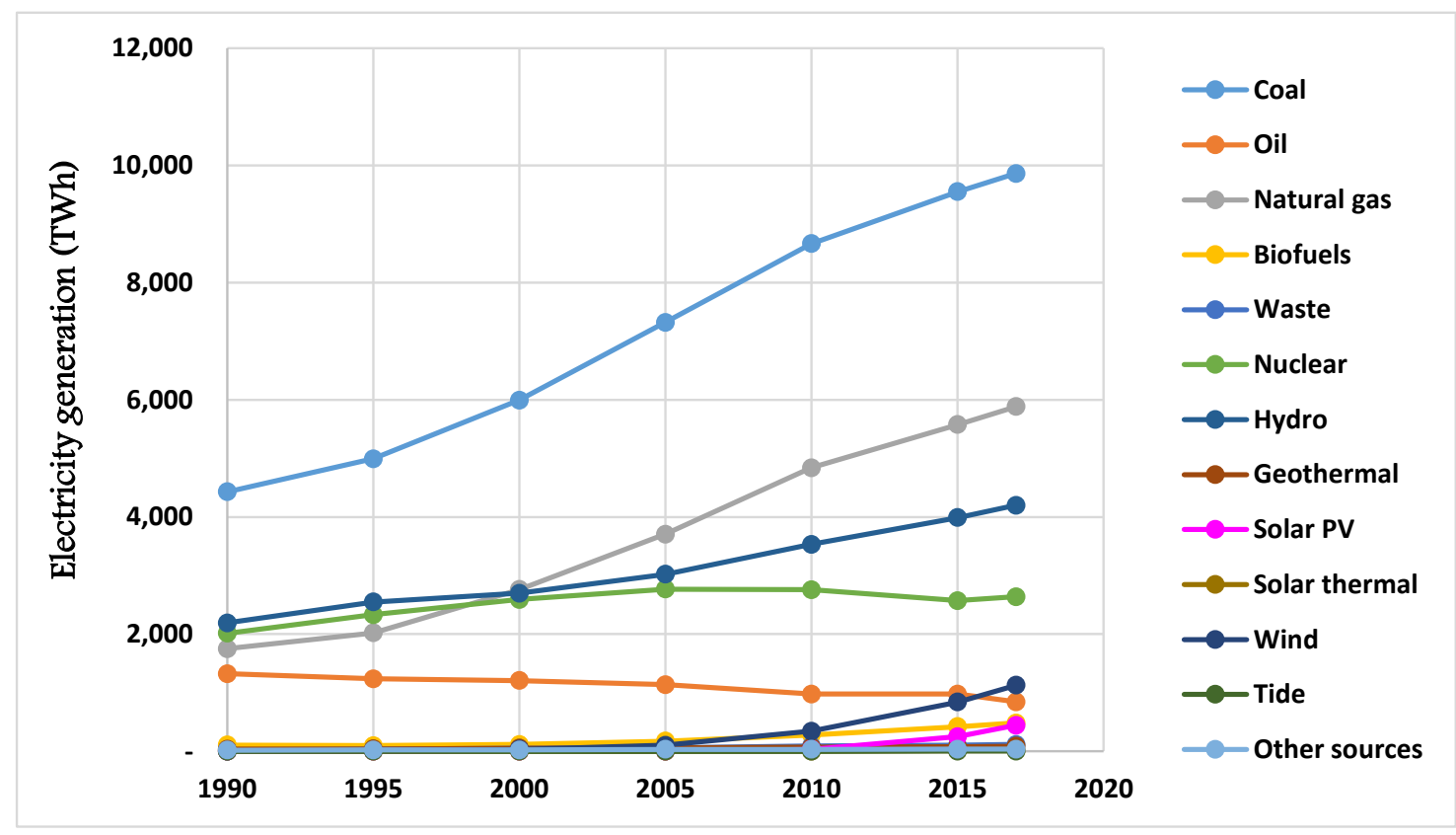

Figure 1. Global electricity generation by the source (1990-2017) [2].

For all the reasons mentioned previously, clean energy sources and carbon capture and storage (CCS, used acronyms presented in Table A1) methods are being focused on recently [9]. Biomass with carbon capture and storage (Bio-CCS or BECCS) is of particular interest, as negative emissions can be achieved [10,11]; thus, this technology could become very popular in the future. The building sector also accounts for a large amount of electricity consumption, therefore architecture design could also be another technique to reduce energy consumption [12].

\subsection{Life-Cycle Assessment (LCA) of Electricity Generation}

With the steadily growing economy of newly industrialized countries such as India or Indonesia, the damage caused in the environmental impact categories cited above could keep growing in the future if no measures are taken to mitigate the effect of population and economic growth on energy consumption. 
Several life-cycle assessment (LCA) studies have tried to tackle the problems caused by the growing electricity consumption by estimating the emissions of different electricity generation sources. LCA is a useful technique to assess the environmental impacts of a product or services throughout its entire life-cycle, from the extraction of raw materials through to processing, transport, use and recycling/disposal. By considering several different impacts over the entire life-cycle, it is possible to identify potential tradeoffs from one life-cycle stage to another or from one environmental problem to another. These are major differences with the other assessment methods such as the carbon/water footprint (focusing only on one environmental aspect) or the methods focusing only on the direct emissions of products during operation. Each electricity generation source has a different lifecycle, so it is important to compare them at the same level. The main options are presented in Figure 2.

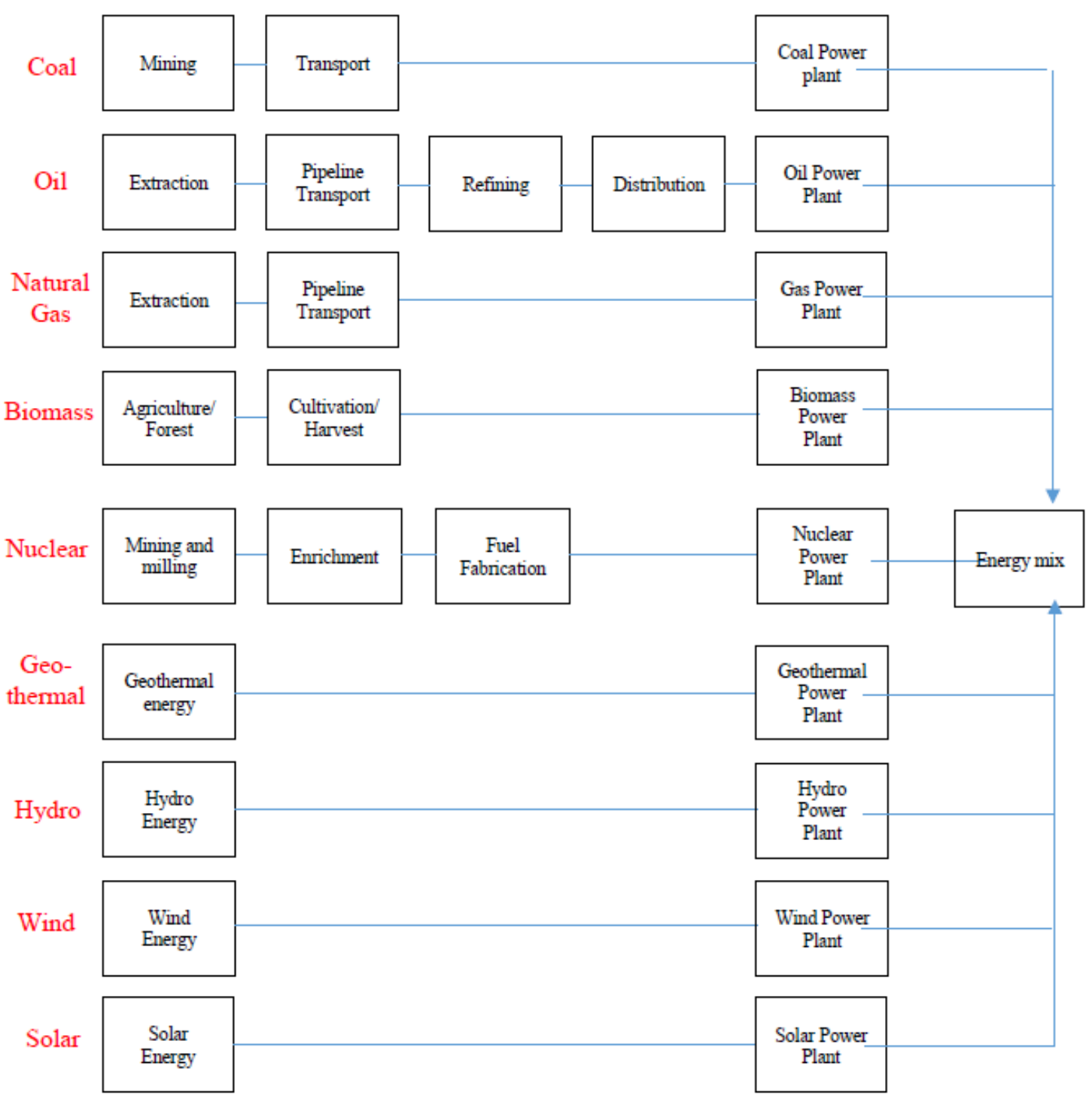

Figure 2. Lifecycle of the main electricity generation options (adapted from [13]).

Coal-based systems have various impacts: on water use, due to coal mining, washing, and processing [14]; on land use due to infrastructure [15]; and on fossil resources [16]. More importantly, coal has an impact during the operational stage of a plant, especially due to the combustion of coal emitting a large amount of greenhouse gases (GHGs) and air pollutants [8].

Oil and natural gas systems also have an impact on climate and air pollution during the operation stage [8], as well as on oil [17] and natural gas [18] scarcity due to fossil-fuel consumption. 
Biomass systems have impacts during the cultivation/harvest stage, especially on land use and climate change [19] but also during combustion, depending on the type of biomass used [20].

Nuclear systems are proven to have a small impact on carbon dioxide emissions and air pollutants [21]; however impacts (land use and resource consumption) occur during the mining and enrichment of uranium and also due to the water required to create the steam needed for electricity generation and to cool the reactors during operation [22]. Nuclear waste may also contribute to ionizing radiation [23]. Other potential risks that have failed to be addressed by the LCA also exist, and various incidents can occur, such as in Chernobyl (1986) or, more recently, in Fukushima (2011).

Hydro systems have impacts on water use [24] and resource depletion due to the components required for their systems' construction [25]. Land transformation also occurs when using hydropower through infrastructure construction (namely, via power lines and access roads) [26].

Wind and solar systems have impacts on resource depletion due to the components required for photovoltaic panels and wind turbines, especially depletion of copper and chromium [25].

The latest findings for the LCA on electricity generation are summarized in Table A2. For conventional plants, such coal- and natural-gas-based systems, the literature has been focusing for example on the implementation of negative emissions technologies aimed at capturing carbon dioxide emissions or also on retrofitting existing coal power plants. For renewables, several systems (biomass, hydro, power, and solar) in different locations (China, Denmark, Spain, etc.) have been evaluated, an attention was given to infrastructural materials. Some assessments have been provided for developing countries as well (e.g., Bangladesh). Based on the environmental impacts raised in this recent review, it is still not intuitive to identify which technology has the overall best environmental performance.

For that purpose, Turconi et al. (2013) [8] conducted a review of 167 case studies found in the literature and reported that the range of values for carbon dioxide emissions was large depending on the source: between 2 (hydropower) and $1050 \mathrm{~kg} \mathrm{CO}$ eq/MWh (hard coal). Similarly, the same trend for these two technologies was observed for $\mathrm{NOx}$ and $\mathrm{SO}_{2}$ emissions: 0.004-3.9 kg NOx/MWh and 0.001-6.7 $\mathrm{kg} \mathrm{SO}_{2} / \mathrm{MWh}$; all these findings are shown in Table A3.

In a similar vein, Laurent et al. (2018) [27] identified the lifecycle environmental hotspots for electricity generation. They showed that fuel combustion during power-plants operation has the greatest impacts for fossil-based electricity; however, when using renewables, resource extraction stages for power-plants construction mainly influence the results. The main findings are shown in Table 1. The authors noted that it is important to consider all life cycles stages while dealing with energy system as for decision makers, it is important not to shift the environmental burden from one stage to another.

Table 1. Lifecycle environmental hotspots of electricity generation (adapted from [27]).

\begin{tabular}{cccccccccc}
\hline $\begin{array}{c}\text { Impact } \\
\text { Category }\end{array}$ & Coal & $\begin{array}{c}\text { Natural } \\
\text { Gas }\end{array}$ & Oil & Nuclear & Wind & Solar & Hydro & Geo-Thermal & Biomass \\
\hline $\begin{array}{c}\text { Climate } \\
\text { Change }\end{array}$ & Operation & Operation & Operation & Operation & Resource & Resource & Resource & Resource & Operation \\
\hline $\begin{array}{c}\text { Particulate } \\
\text { Matter }\end{array}$ & Operation & Operation & Operation & Operation & Resource & Resource & Resource & Resource & Operation \\
\hline $\begin{array}{c}\text { Water Use } \\
\text { Land Use }\end{array}$ & Operation & Operation & Operation & Operation & Resource & Resource & $\begin{array}{l}\text { Resource/ } \\
\text { Operation }\end{array}$ & Resource & Operation \\
\hline $\begin{array}{c}\text { Fossil } \\
\text { Depletion }\end{array}$ & Operation & Operation & Operation & Operation & Resource & Resource & Resource & Resource & Operation \\
\hline $\begin{array}{c}\text { Metal } \\
\text { Depletion }\end{array}$ & $\begin{array}{c}\text { Resource/ } \\
\text { Operation }\end{array}$ & $\begin{array}{l}\text { Resource/ } \\
\text { Operation }\end{array}$ & $\begin{array}{l}\text { Resource/ } \\
\text { Operation }\end{array}$ & Operation & $\begin{array}{l}\text { Resource/ } \\
\text { Disposal }\end{array}$ & $\begin{array}{c}\text { Resource/ } \\
\text { Disposal }\end{array}$ & $\begin{array}{c}\text { Resource/ } \\
\text { Disposal }\end{array}$ & $\begin{array}{c}\text { Resource/ } \\
\text { Disposal }\end{array}$ & $\begin{array}{c}\text { Resource/ } \\
\text { Disposal }\end{array}$ \\
\hline
\end{tabular}




\subsection{External Cost of Electricity Generation}

Another type of evaluation was performed by the European Environment Agency (EEA); the goal was to estimate the external cost of electricity generation in the EU [28]. According to the report, the external cost can be defined as the impact of an activity on an external group was not originally taken into account. Indeed, the costs associated with environmental damages for example on human health or ecosystems are not currently accounted for by the producers or the consumers of electricity, these costs can be significant and should not be underestimated. Their consideration can be useful to establish a ranking between different energy options and thereby support decision-making. In the EEA study, external cost was based on three major components: climate-change damage due to $\mathrm{CO}_{2}$, air-pollutant emissions damage, and the nonenvironmental social cost for electricity not produced from fossil fuels. An environmental impact assessment expressed as a monetary value enables to increase the interest of decision makers, as it offers a more comprehensive approach to understand what the entire potential impact could be. It also allows us to establish a trade-off between different technologies to determine the pros and the cons of each one. The average external cost for EU25 in 2005 was found to be between 0.018 (low estimate) and $0.060 € / \mathrm{kWh}$ (high estimate). A similar approach was applied on a city, country, or regional level in different case studies; a summary is provided in Table 2.

In this table, the external costs are between less than 0.001 and $0.375 \$ / \mathrm{kWh}$. Coal and lignite technologies have the highest impact, whereas renewables have the lowest.

On a global scale, Rafaj and Kypreos (2007) [29] demonstrated that the external cost of electricity is usually found to be $20 \%$ higher when considering the impact of $\mathrm{CO}_{2}$ emissions in addition to air pollutants. In contradiction to the common thinking that fossil fuels have the highest impacts, Stremikiene et al. (2014) [30] found that biomass (straw) CHP with an extraction-condensing turbine had the highest impact due to climate change. Although many studies focus on air-pollution's impact, its magnitude is different in each study. By comparing Vrhocek et al. (2005) [31] and Dimitrijevic et al. (2011) [32], it can be observed that, even though both studies focused on countries located in the same region (the Balkans) and considered the same pollutants ( $\mathrm{PM}, \mathrm{SO}_{2}$, and $\left.\mathrm{NOx}\right)$, the results were very different. The emissions inventory from power-plants for PM and NOx showed many similarities; however, $\mathrm{SO}_{2}$ emissions per $\mathrm{kWh}$ in some locations are up to 10 times higher in Bosnia than in Croatia due to the absence of abatement equipment for the mitigation of sulphur emissions. As shown by Czarnowska and Frangopoulos (2012) [33] and Klaassen (2007) [34], the damages caused by air pollution are directly linked to the amount of emissions and population density in the region. Mahapatra (2012) [35] also found that not only electricity generation had an impact on air substances emissions but also the energy supply.

Table 2. Overview of the previous studies' estimates of external cost.

\begin{tabular}{|c|c|c|c|c|c|c|}
\hline $\begin{array}{c}\text { Impact } \\
\text { Considered }\end{array}$ & Power-Plant Type & Low $(\$ /$ kWh $)$ & High (\$/kWh) & Location & Year & Reference \\
\hline $\mathrm{CC}, \mathrm{AP}$ & C, Bio & 0.009 (Bio) & 0.026 (Coal) & China & 2019 & [36] \\
\hline $\mathrm{CC}, \mathrm{AP}$ & WTE & 0.99 & 0.99 & Spain & 2019 & [37] \\
\hline $\mathrm{CC}, \mathrm{AP}$ & $\mathrm{C}, \mathrm{L}$ & $0.041(\mathrm{C})$ & $0.082(\mathrm{~L})$ & Poland & 2018 & [38] \\
\hline $\mathrm{AP}$ & C, NGC, NGCC & 0.019 & 0.089 & Iran & 2015 & [39] \\
\hline $\mathrm{AP}, \mathrm{CC}, \mathrm{R}$ & $\begin{array}{c}\text { Bio, C, Li, N, } \\
\text { NGCC, O, S, W }\end{array}$ & $0.001(\mathrm{H})$ & 0.078 (Bio) & Lithuania & 2014 & [30] \\
\hline $\mathrm{AP}, \mathrm{CC}, \mathrm{SOC}$ & $\mathrm{C}$ & 0.029 & 0.25 & $\begin{array}{l}\text { Northern } \\
\text { Poland }\end{array}$ & 2012 & [33] \\
\hline $\mathrm{AP}, \mathrm{CC}$ & $\mathrm{C}$ & 0.046 & 0.046 & $\begin{array}{l}\text { Western } \\
\text { India }\end{array}$ & 2012 & [35] \\
\hline $\mathrm{AP}$ & $\mathrm{Li}$ & 0.002 & 0.035 & Turkey & 2011 & [40] \\
\hline $\mathrm{AP}$ & $\mathrm{C}$ & 0.115 & 0.225 & $\begin{array}{l}\text { Bosnia and } \\
\text { Herzegovina }\end{array}$ & 2011 & [3] \\
\hline
\end{tabular}


Table 2. Cont.

\begin{tabular}{|c|c|c|c|c|c|c|}
\hline $\begin{array}{c}\text { Impact } \\
\text { Considered }\end{array}$ & Power-Plant Type & Low (\$/kWh) & High (\$/kWh) & Location & Year & Reference \\
\hline $\mathrm{CC}$ & $\mathrm{Li}, \mathrm{NG}, \mathrm{O}$ & 0.014 (NG) & $0.034(\mathrm{Li})$ & Greece & 2010 & [41] \\
\hline $\mathrm{AP}, \mathrm{CC}, \mathrm{SOC}$ & $\begin{array}{c}\text { Bio, C, H, Li, N, } \\
\text { NGCC, O, P, S, W }\end{array}$ & $<0.001(\mathrm{H}, \mathrm{W})$ & $0.240(\mathrm{Li})$ & EU25 & 2008 & [28] \\
\hline $\mathrm{AP}$ & $\begin{array}{c}\text { C, O, NG, Bio, N, } \\
\text { W, S }\end{array}$ & $0.001(\mathrm{~S}, \mathrm{~W})$ & $0.375(\mathrm{C})$ & Global & 2007 & [34] \\
\hline $\mathrm{AP}, \mathrm{CC}$ & $\begin{array}{l}\text { Bio, C, Geo, H, } \\
\text { NG, O, N, S, W }\end{array}$ & $0.001(\mathrm{H}, \mathrm{S}, \mathrm{W})$ & $0.177(\mathrm{C})$ & Global & 2007 & [29] \\
\hline $\mathrm{AP}$ & $\mathrm{O}$ & 0.008 & 0.013 & Cuba & 2007 & [42] \\
\hline $\mathrm{AP}$ & $\mathrm{C}, \mathrm{NG}, \mathrm{O}$ & 0.001 (NG) & $0.007(\mathrm{NG}, \mathrm{O})$ & Croatia & 2005 & [31] \\
\hline $\mathrm{AP}, \mathrm{CC}$ & $\mathrm{C}$ & 0.021 & 0.144 & South Africa & 2003 & [43] \\
\hline
\end{tabular}

AP: air pollution; Bio: biofuel; CC: climate change; C: coal; Geo: geothermal; H: hydropower; Li: lignite; N: nuclear; NG: natural gas; NGC: NG conventional; NGCC: NG combined cycle; O: oil; P: peat; R: resource S: solar; SOC: Social cost; W: wind. WTE: Waste-to-Energy.

Several points can be observed from the previous table:

- Previous research has tended to only focus on the impact of air pollution or climate change, which could easily lead to an underestimation of the damages;

- Several studies only consider the operational stage (electricity generation stage), which is not adapted for the assessment of renewables;

- Only three studies covered the entire range of possibilities for different electricity generation sources;

- Rafaj and Kypreos (2007) [29] and Klaassen et al. (2007) [34] are the only studies to establish a comparison on a global scale. However, their models only estimate the external cost at the continental or global level, which is a serious limitation because, for example, the situation between western and eastern Europe is completely different (with a higher reliance on renewables in the former area and a higher reliance on coal (especially lignite) in the latter);

- The two previous studies were published more than 10 years ago, so they do not take into account current technological progress or the shift in the energy mix, which both have a strong influence on the results [28].

Thus, the different types of impact previously noted in this study, such as resource consumption (mineral, fossil, and water) and land transformation, have not been considered yet in the literature. Consequently, it is important to consider all available technologies and extend the number of environmental impact categories to properly assess the impacts of renewables. Differences between countries (efficiency of power plants, population density, and land-use planning) have important potential impact on the results, as highlighted in previous studies. Looking at the important differences of the results between studies with a range between less than $0.001 \$ / \mathrm{kWh}$ and $0.375 \$ / \mathrm{kWh}$ due to the different types of models applied, which are either only taking into account either one type of impact category, analyzing the impact of coal-power plant only, or the emissions at only one specific location. It would be better to compare different location using the same framework, considering for each location: a larger number of environmental impact categories, the differences of power-plant direct emissions, the difference of population density in each region but also considering the impacts of the mining stage and the following energy supply until electricity generation.

The aim of this paper is to fill the previous research gaps and to estimate, with transparency, the recent external costs of electricity generation at a global scale in G20 countries by considering a wider range of impact categories, including, for example land occupation and resource consumption and the full life-cycle of electricity generation, to provide a more accurate analysis of different electricity-generation technologies and evaluate most of the possibilities existing in the current market 
in each country. Despite the recent rise of the environmental concerns, these external costs are still not considered when dealing with energy prices. One of the reasons might be the difficulty to understand the complex environment models but also the absence of tools specific to each region.

To achieve this transparent analysis, an approach based on life-cycle thinking was adopted: The life cycle impact assessment method based on endpoint modeling (LIME3) [44-46] was used to evaluate the environment impact assessment. For the choice of the global LCIA method, recently several studies provided regionalized-impact factors: Recipe2016 [47], ImpactWorld+ [48], and LIME3. In addition to the wide coverage of impact categories (climate change [49,50], air pollution [51], photochemical-oxidant creation [52], water consumption [53], land use [54], mineral-resources, fossil-fuels, forest-resource consumption, and solid waste) and their impacts on four areas of protection (human health, social assets, biodiversity, and primary production), the main advantage of LIME3 is the introduction of weighting factors that are specific to each country and help ultimately to provide a single indicator expressed in a monetary value (\$). This is particularly well-adapted for the evaluation of electricity, as a comparison can later be made between the market price and the external electricity cost. The two others global LCIA methods do not give any specific indications concerning weighting, and only provide the midpoint and endpoint characterization expressed as a specific unit of emissions or consumption for each impact category, for example, in disability-adjusted life year (DALY)/kgPM2.5. Therefore, these methods cannot be used to estimate an external cost contrary to LIME3.

\section{Materials and Methods}

\subsection{Goal and Scope}

The goal of the study was to evaluate the external cost of electricity generation in G20 countries using a global life-cycle impact-assessment (LCIA) method (LIME3) by considering 7 enviromental impact categories: climate change, air pollution, photochemical oxidants, water consumption, land use, mineral resource consumption, and fossil fuel consumption. At first, an evaluation for each type of electricity-generation technology in each country was perfomed for the generation of $1 \mathrm{kWh}$ (high voltage). Then, the evaluation of $1 \mathrm{kWh}$ (low voltage) from the power generation mix of each country was assessed; system boundaries are provided in Figure 3. It includes the life cycle of the infrastructure, which generates electricity (including for example materials and their transport required to build the infrastructure) and the life cycle of fuels (not relevant for renewables) with the inclusion of the stages presented in Figure 2. The high-voltage processes describe the situation until the plant operation, before any further transformation, whereas the low-voltage processes describe the situation until the household level.

The European Union (EU) was excluded from our study, as several disparities (e.g., their reliance on fossil fuels, the efficiency of their power plants, etc.) currently exist between the member states. Therefore, the average external costs of the 27 nations would not be meaningful. However, France, Germany, and Italy, which are all individually G20 members, were included. The common targets in the EU have only been established in recent years: to increase the share of energy consumption from renewable sources and improve energy efficiency in order to reduce the use of primary energy [55].

The approach used in this study is detailed in Figure 4. Resources consumption and emissions that have an environmental impact during the electricity generation life-cycle are taken into account and later assigned to environmental impact categories (detailed in Section 2.3). These different impacts having damages on the area of protection such as human health or biodiversity. These damages are expressed in their own specific unit (e.g., DALY) therefore an economic weighting is applied to convert and aggregate these damages into a single monetary value: the external cost. 


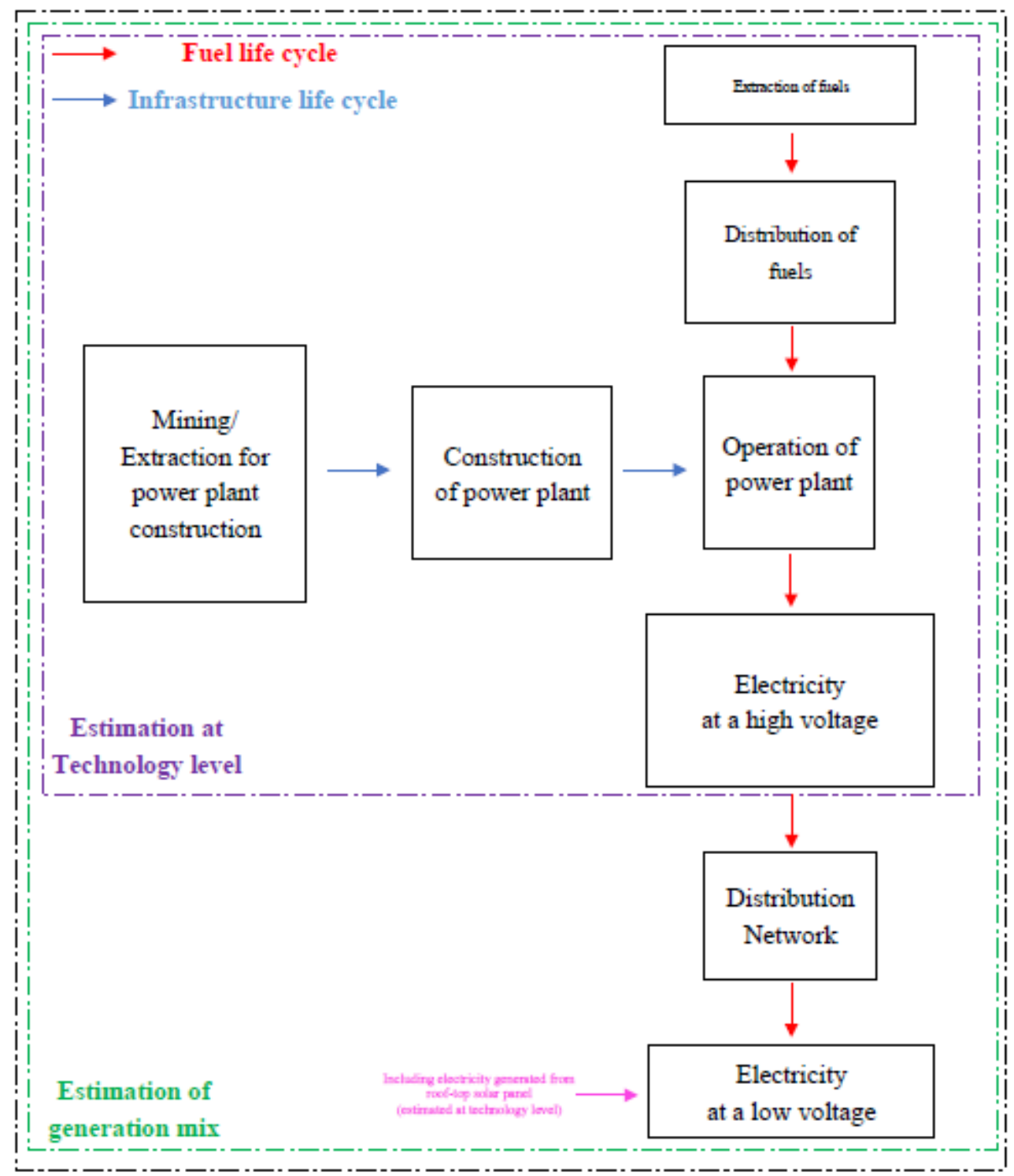

Figure 3. Studied system boundaries.

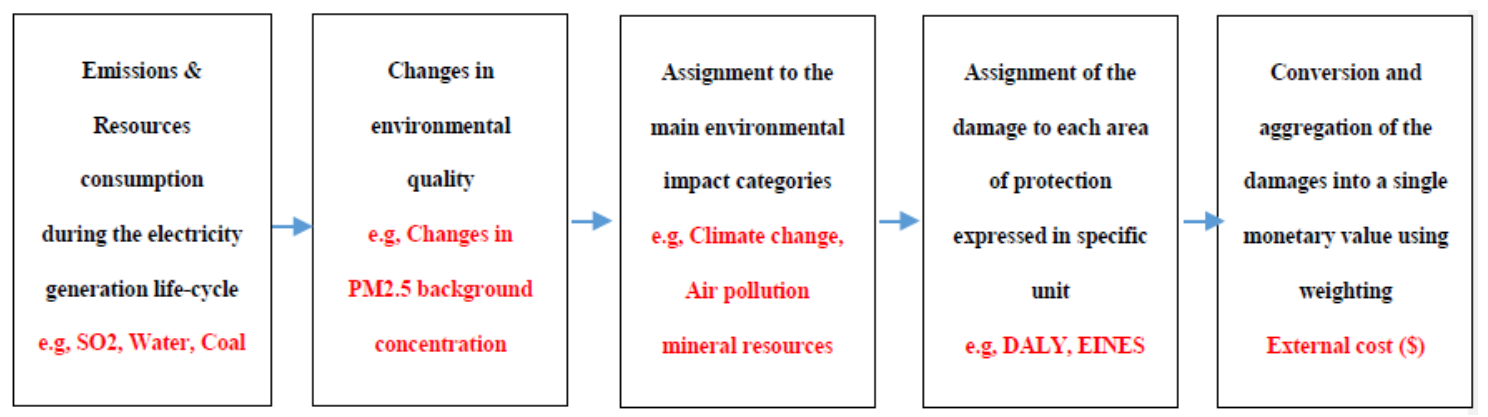

Figure 4. Pathway to estimate the external cost.

\subsection{Inventory}

IEA (International Energy Agency) data (2017) [56] were used as presented in Figure 5. These data are contained in the Ecoinvent Database v3.4, which is included in SimaPro 8. They correspond to global electricity generation in 2014 (for each country), and are the latest data available in the database. Ecoinvent database also provides a qualitative analysis of energy loss though the network and covers a 
wider range of inventory flows than other available LCI databases. According to this information, Saudi Arabia, South Africa, and Indonesia have the highest dependence on fossil fuels $(100 \%, 92 \%$, and $86 \%$ of the energy mix, respectively). On the other hand, France, Canada, and Brazil have the lowest dependence $(5 \%, 20 \%$, and $24 \%$ of the mix, respectively). Concerning electricity generation from renewable energy (hydropower, solar, and wind energy), Brazil, Canada, and Italy are the leading G20 countries $(65 \%, 62 \%$, and $35 \%$ of the mix). Reliance on biofuels is quite low for the G20 (3\% in the nonweighted average of the G20 energy mix), but Germany (9\%), the UK (8\%), Italy (8\%), and Brazil ( $8 \%)$ still rely on them. This inventory provides electricity data for three types of voltages: low, medium, and high.

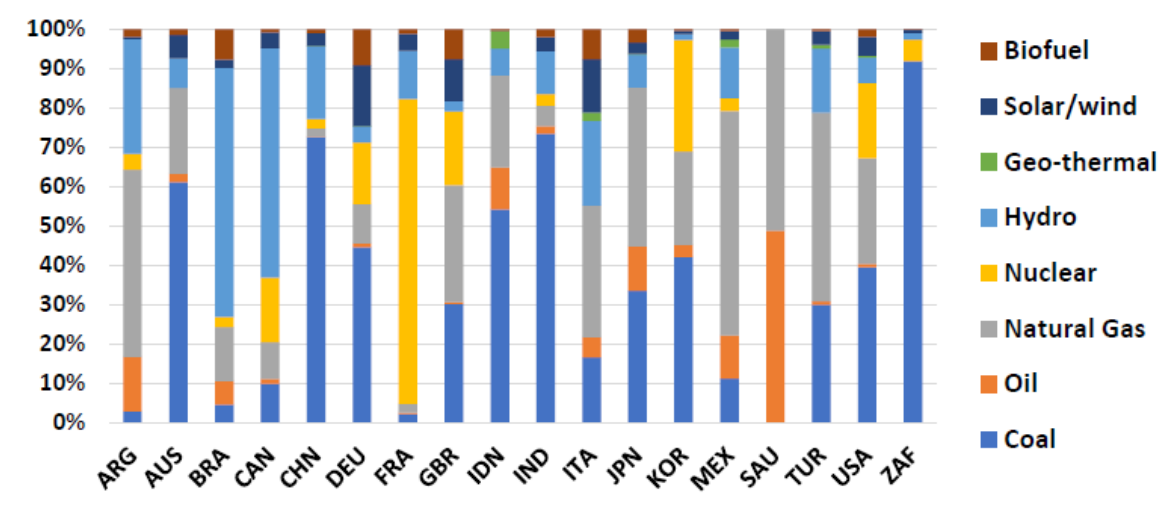

Figure 5. Electricity generation by source.

Following the Ecoinvent database structure, low-voltage processes were chosen to determine the impact of the grid mix for each country, and high voltage processes to determine the impact of each type of power plant. Almost all current possibilities available on the market were evaluated in this study, as shown in Table 3. Several types of plants were considered in this study, as shown in Table 3. Within each category, some differences can be briefly highlighted:

- Coal: In comparison to hard coal, lignite (also referred sometimes as brown coal) is the lowest grade coal with higher emissions of carbon dioxide and air pollutants during combustion.

- Natural gas: A combined cycle power plant combines both a gas and a steam turbine together for better efficiency than conventional plants.

- Wind: Both onshore and offshore options have pros and cons. Onshore wind farms are currently the most popular type of wind farm for economical reasons (with higher maintenance and supply costs for offshore turbines).

- Hydro: In run-of-river sytems, water flows from a river though a canal or penstock to spin a turbine; in pumped-storage systems composed of a lower and upper reservoir, during high demand, the water is pumped from the upper reservoir to spin a turbine and produce electricity; in reservoir systems, a dam is used to store water, which is later released to spin turbines and produce electricity.

- $\quad$ Nuclear: Both boiling water and pressure water reactors use nuclear energy as fuel and water to generate steam and cool the reactors. However, a pressure water reactor uses two water circuits, while boiled water generates steam using only one water circuit.

- Solar: Open ground facilities can generate much more energy than simple roof-top panels; however, they require the occupation of land. 
Table 3. Type of power plants considered in this study.

\begin{tabular}{cccc}
\hline Category & Type 1 & Type 2 & Type 3 \\
\hline Coal & Hard Coal (HC) & Lignite & - \\
Natural Gas & Conventional (C) & Combined Cycle (CC) & - \\
Oil & Oil & - & - \\
Wind & Onshore (ON) & Offshore (OFF) & - \\
Geothermal & Geothermal (GEO) & - & - \\
Hydro & Run of River (RR) & Pumped Storage (PS) & Reservoir (R) \\
Nuclear & Boiling Water (BW) & Pressure Water (PW) & - \\
Solar & Open Ground (OG) & Roof & - \\
\hline
\end{tabular}

The following inventory items were chosen from the Ecoinvent database: carbon-dioxide emission $\left(\mathrm{CO}_{2}\right)$, sulfur-dioxide emission $\left(\mathrm{SO}_{2}\right)$, nitrogen-oxide emission (NOx), nonmethane volatile organic compounds emission (NMVOC), particle-matter 2.5 emission (PM2.5), oil consumption, coal consumption, natural-gas consumption, water consumption, land transformation and occupation, and mineral consumption.

\subsection{Impact Assessment}

LIME3 was utilized for external-cost evaluation. Nine impact categories and four endpoints (human health, social assets, biodiversity, and primary production) are included in this method, as illustrated in Figure 6 (additionally, to facilitate the understanding of our study, a detailed explanation of the parameters included in this method is provided (Tables A4 and A5). The impacts of solid waste and forest resources, however were not considered in our study. As stated previously, the possibility to include a large set of impact categories and provide results using a single indicator were the motivation to use this method. LIME3 also provides damage factors for up to 193 countries in the world, so it was very well-adapted to evaluate the external cost of electricity on a global scale. Finally, another advantage of LIME3 is its consideration of trade between countries, which allows one to adequately estimate the damage caused in mining countries when a resource unit is consumed in the consumer country. A discount rate was also included $(3 \%, 5 \%$, or $7 \%)$ to integrate the impact of future cash flows, as this rate represents how much importance is given to current decisions concerning future resource scarcity, a lower rate highlights the higher stress placed on the necessity for resource savings and $5 \%$ was chosen in this study.

The external cost (EC) in LIME3 can be viewed as the product of two items: the inventory result and the integration factor (IF), which is itself the product of the damage factor (or endpoint characterization factor) and the G20 population-weighted average economic-value conversion factor specific to each area of protection:

$$
\begin{gathered}
\mathrm{EC}_{\text {country }}=\sum_{\text {Impact safe }} \sum_{\mathrm{X}} \sum_{\operatorname{Inv}_{\text {country }}(\mathrm{X}) \times I F_{\text {country }}^{\text {impact }}(\text { Safe, } \mathrm{X})} \\
I F_{\text {country }}^{\text {impact }}(\text { Safe }, \mathrm{X})=I F_{\text {country }}^{\text {impact }}(\text { Safe }, \mathrm{X}) \times \mathrm{EV}_{\mathrm{G} 20 \text { pop-weighted }}(\text { Safe })
\end{gathered}
$$

where:

- $\operatorname{Inv}(X)$ is the amount of inventory item $X$;

- $\quad I F^{\text {impact }}$ is the integration factor associated with "Impact", which is caused by inventory item $X$ extended to the area of protection "Safe";

- DFimpact is the damage factor associated with "Impact", which is caused by inventory item X extended to the area of protection "Safe";

- $\quad \mathrm{EV}(\mathrm{Safe})$ is the economic-value conversion factor based on weighting for the damage of one unit of the area of protection "Safe". 


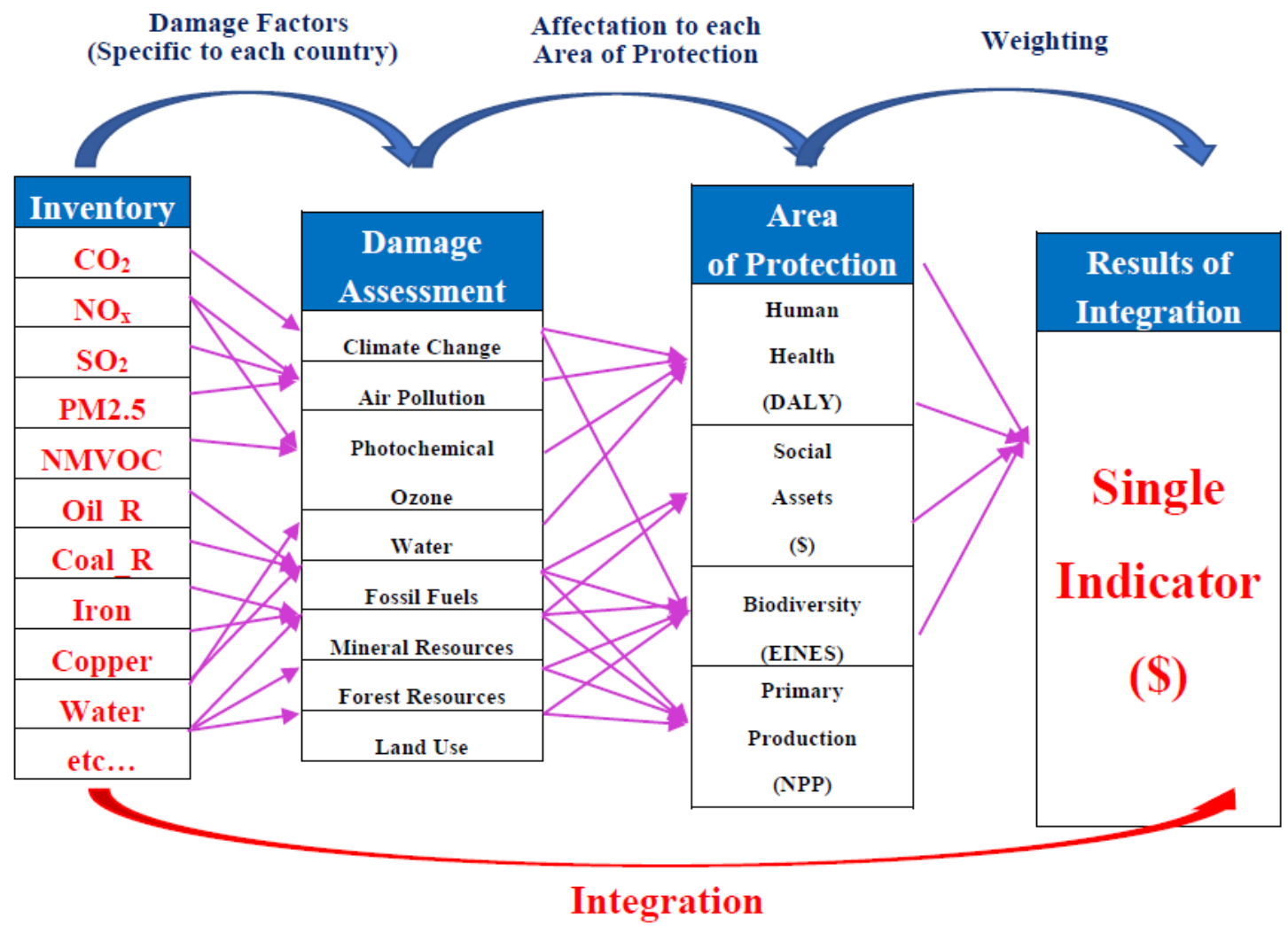

Figure 6. Life cycle impact assessment method based on endpoint modeling (LIME3) framework.

For example, " $\mathrm{X}$ " is the total $\mathrm{SO}_{2}$ emissions, "Impact" is the air pollution, and "Safe" is human health. $\mathrm{SO}_{2}$ emissions are then expressed in $\mathrm{kg}$, the damage factor in disability-adjusted life years (DALY)/ $/ \mathrm{kg}_{\mathrm{SO}}$, and the economic-value conversion factor in \$/DALY; thus, the integration factor can be directly expressed in $\$ / \mathrm{kg}_{\mathrm{SO} 2}$.

The economic value conversion factors in LIME3 were developed based on the willingness to pay (WTP), following a survey conducted among all G20 members, a total of 6400 responses were obtained. It was determined how much the responders were willing to pay to avoid damages in each area of protection. Based on the answers, it was revealed which areas of protection were prioritized in each G20 country. In this study, economic-value conversion factors for each country were selected to be identical based on the average G20 country weighting factor (Murakami et al. (2018) [46]), as presented in Table 4.

Table 4. Economic value conversion factors for G20 countries (G20 population weighted average).

\begin{tabular}{cccc}
\hline $\begin{array}{c}\text { Human Health } \\
\text { (USD/DALY) }\end{array}$ & $\begin{array}{c}\text { Biodiversity } \\
\text { (USD/EINES) }\end{array}$ & $\begin{array}{c}\text { Social Assets } \\
\text { (USD/USD) }\end{array}$ & $\begin{array}{c}\text { Primary Production } \\
\text { (USD/kg) }\end{array}$ \\
\hline $2.3 \times 10^{4}$ & $1.10 \times 10^{10}$ & 2.5 & $5.6 \times 10^{-2}$ \\
\hline
\end{tabular}

\section{Results}

\subsection{External Cost Estimation of Each Technology in G20 Countries}

To find an explanation for the external cost of electricity for the G20 country power generation mix, it was necessary to evaluate the impact of each technology for each country. A summary of these results is provided in Table 5 . The inventory items having influence on the external cost for each system are described in Table A6. 
Table 5. External cost for each technology in each G20 country ( $\$ / \mathrm{kWh}$; from dark green (Low) to dark red (High), the different hydropower systems are left uncoloured).

\begin{tabular}{|c|c|c|c|c|c|c|c|c|c|}
\hline & \multirow{2}{*}{ HC } & \multirow{2}{*}{ Lignite } & \multirow{2}{*}{$\begin{array}{c}\mathrm{NG} \\
\mathrm{C} / \mathrm{CC}\end{array}$} & \multirow{2}{*}{ Oil } & \multirow{2}{*}{$\begin{array}{c}\text { Wind } \\
\text { ON/OFF }\end{array}$} & \multirow{2}{*}{ GEO } & \multirow{2}{*}{$\begin{array}{c}\text { Hydro } \\
\text { RR/PS/R }\end{array}$} & \multirow{2}{*}{$\begin{array}{l}\text { Nuclear } \\
\text { BW/PW }\end{array}$} & \multirow{2}{*}{$\begin{array}{c}\text { Solar } \\
\text { OG/Roof }\end{array}$} \\
\hline & & & & & & & & & \\
\hline ARG & - & - & $-/-$ & - & $-/$ & - & $-/-/-/-$ & -1 & - \\
\hline AUS & 0.026 & 0.026 & $0.013 / 0.008$ & 0.096 & $0.002 /-$ & - & $0.000 / 0.031 /-$ & $-/$ & $0.004 / 0.003$ \\
\hline BRA & 0.023 & 0.047 & $0.013 / 0.009$ & 0.081 & $0.003 /-$ & - & $-/-/ 0.002$ & $-/ 0.001$ & $-/ 0.006$ \\
\hline CAN & 0.034 & 0.029 & $0.022 / 0.014$ & 0.071 & $0.004 /-$ & - & $0.001 / 0.017 / 0.002$ & $-/ 0.004$ & $0.008 / 0.009$ \\
\hline CHN & 0.101 & - & $0.021 / 0.020$ & 0.146 & $0.009 / 0.006$ & 0.009 & $0.001 / 0.112 /-$ & $-/ 0.004$ & $0.015 / 0.014$ \\
\hline DEU & 0.021 & 0.027 & $0.019 / 0.012$ & 0.083 & $0.005 / 0.004$ & 0.005 & $0.001 / 0.024 / 0.004$ & $0.002 / 0.002$ & $0.011 / 0.010$ \\
\hline FRA & 0.037 & - & $0.017 / 0.012$ & 0.087 & $0.003 / 0.003$ & 0.004 & $0.001 / 0.005 / 0.004$ & $-/ 0.002$ & $0.009 / 0.008$ \\
\hline GBR & 0.064 & - & $0.017 / 0.012$ & 0.24 & $0.004 / 0.005$ & 0.007 & $0.001 / 0.058 /-$ & $0.005 / 0.005$ & $0.014 / 0.017$ \\
\hline IDN & - & 0.194 & $0.020 / 0.012$ & 0.133 & $0.002 /-$ & 0.006 & $-/-/ 0.005$ & $-/-$ & $-/ 0.010$ \\
\hline IND & 0.174 & 0.143 & $0.021 / 0.020$ & 0.112 & $0.006 /-$ & 0.009 & $0.001 / 0.227 / 0.068$ & $0.005 / 0.004$ & $-/ 0.010$ \\
\hline ITA & 0.041 & 0.133 & $0.019 / 0.011$ & 0.083 & $0.005 /-$ & 0.005 & $0.001 / 0.028 / 0.006$ & $-\%$ & $0.010 / 0.009$ \\
\hline JPN & 0.036 & - & $0.020 / 0.013$ & 0.041 & $0.005 / 0.005$ & 0.005 & $0.001 / 0.038 / 0.028$ & $0.005 / 0.005$ & $0.011 / 0.010$ \\
\hline KOR & 0.062 & 0.282 & $0.020 / 0.011$ & 0.082 & $0.004 / 0.004$ & - & $0.001 / 0.062 / 0.042$ & $-/ 0.007$ & $0.015 / 0.015$ \\
\hline MEX & 0.027 & 0.043 & $0.022 / 0.014$ & 0.134 & $0.003 /-$ & 0.004 & $0.001 /-/-$ & $0.003 /-$ & $0.009 / 0.005$ \\
\hline RUS & 0.033 & 0.069 & $0.031 / 0.008$ & 0.141 & $0.015 /-$ & 0.004 & $0.000 / 0.032 / 0.002$ & $0.001 / 0.001$ & $-/ 0.008$ \\
\hline SAU & - & - & $0.015 / 0.008$ & 0.046 & $-/-$ & - & $-/-/-$ & $-/-$ & $-/ 0.005$ \\
\hline TUR & 0.048 & 0.141 & $0.014 / 0.009$ & 0.133 & $0.003 /-$ & 0.005 & $0.001 /-/ 0.009$ & $-1-$ & $-/ 0.008$ \\
\hline USA & 0.028 & 0.055 & $0.020 / 0.013$ & 0.138 & $0.003 /-$ & 0.004 & $0.001 / 0.029 / 0.011$ & $0.002 / 0.002$ & $0.007 / 0.007$ \\
\hline ZAF & 0.035 & - & $-/ 0.007$ & 0.047 & $0.006 /-$ & 0.004 & $0.001 / 0.049 / 0.013$ & $-/ 0.002$ & $-/ 0.009$ \\
\hline AVG & 0.049 & 0.099 & $0.019 / 0.012$ & 0.105 & $0.005 / 0.005$ & 0.005 & $0.001 / 0.055 / 0.015$ & $0.003 / 0.003$ & $0.011 / 0.009$ \\
\hline
\end{tabular}

Some interesting findings can be highlighted:

For hard coal (HC), the results were between 0.021 (Germany) and $0.174 \$ / \mathrm{kWh}$ (India): the emissions of PM2.5 for $1 \mathrm{kWh}$ of electricity generated using coal in India were almost seven times higher than the G20 average $(2.5 \mathrm{~g} / \mathrm{kWh})$. The PM2.5 integration factor was also the highest in the G20 with $36 \$ / \mathrm{kg}$ due to higher population density. India had a population density of 416 inhabitants $/ \mathrm{km}^{2}$ compared with the 25 inhabitants $/ \mathrm{km}^{2}$ in Brazil, resulting in a much smaller integration factor for PM2.5 (1.8 \$ $/ \mathrm{kg}$ ). In addition, Germany had the lowest emissions of $\mathrm{SO}_{2}, \mathrm{NOx}$, and PM2.5 from coal power-plants among G20 countries due its technological performance.

For lignite, the results were between 0.026 (Australia) and $0.282 \$ / \mathrm{kWh}$ (South Korea). For South Korea, the results were mainly explained by the impact of PM2.5: even if the emissions per kWh $(0.0088 \mathrm{~kg})$ were close to the G20 emissions average, the integration factor of PM2.5 for South Korea was high ( $25 \$ / \mathrm{kg})$, the third highest among the studied countries (behind India and China). For Australia, the inventory and integration factors for air pollutants (very low population density of 3 inhabitants $/ \mathrm{km}^{2}$ ) had both lower values than those of other countries.

For natural gas (NG), two types of power plants were assessed for this study: conventional and combined-cycle (CC). For the conventional type, results were found between 0.013 (Australia, Brazil) and $0.031 \$ / \mathrm{kWh}$ (Russia). For Russia both the $\mathrm{CO}_{2}$ and natural-gas consumption inventories show the highest amounts among the $\mathrm{G} 20$ countries. The $\mathrm{CO}_{2}$ emissions of conventional plants in Russia are two times higher than the G20 average, but the national reserves of natural gas in the country are the highest in the world. Thus, the impact on this resource was still limited (0.001\$). Indeed, as detailed in Table A5, the damage factors for fossil fuels and resource consumption in LIME3 are based on yearly extraction compared to the actual reserves [57]; the smaller the ratio is, the lower the damage factor is. Global trade was also taken into account in LIME3; as a result, a country that imports resources from another where scarcity was low (e.g., oil from Saudi Arabia) had a smaller damage factor. On the other hand, a country that had limited reserves and mainly used these resources had a higher damage factor 
(e.g., oil in Argentina). For Turkey, natural-gas imports were mainly from Russia, and $\mathrm{CO}_{2}$ emissions were also on the same level of the G20 country average, so impacts were limited. Australia and Brazil both show lower air-pollutant impact due to their small population density. For combined-cycle plants, results were estimated to be lower than conventional ones, with values between 0.007 (South Africa) and $0.020 \$ / \mathrm{kWh}$ (China, India). Combined-cycle plants had better efficiency, as they required about $30 \%$ fewer resources on average, and $\mathrm{CO}_{2}$ emissions were also reduced at about the same level. The difference of results between countries for this technology were mainly explained by higher natural-gas consumption and more $\mathrm{CO}_{2}$ emissions in China and India, while the air pollution damage in South Africa was low due to the population density.

Oil is the resource with the highest external costs (between 0.041 (Japan) and $0.240 \$ / \mathrm{kWh}(\mathrm{UK})$ ). For Japan, the low cost is explained due to the oil exports from Saudi Arabia, whose reserves are the second highest in the world, with a proven reserve of 266,455 million barrels [58]. For the UK, lower oil reserves coupled with much higher $\mathrm{SO}_{2}$ emissions (almost two times higher than the G20 average) justify this observation.

For wind power, results were between 0.002 (Australia, Indonesia) and $0.015 \$ / \mathrm{kWh}$ (Russia). The difference of impact between onshore $(\mathrm{ON})$ and offshore (OFF) wind turbines was not significant. The impacts mainly come from material consumption (more than $65 \%$ of the total impact); in particular, chromium (26\%); nickel (24\%), as one of the element of stainless steel; and copper (10\%), used for cables.

For hydropower (Hydro), several types of systems were evaluated: Run-of-river (RR), reservoir I, and pumped-storage (PS). The highest cost was determined for pumped storage, with $0.227 \$ / \mathrm{kWh}$ in India; this impact is due to the use of electricity for pumpage, as more than $1.4 \mathrm{kWh}$ of electricity is necessary on average to generate $1 \mathrm{kWh}$ of electricity. Reservoir technology has the second highest impact, especially in countries where the damage factor for water is high, such as Korea $(0.042 \$)$ and Japan (0.028\$). Finally, run-of-river hydropower showed the lowest impact ( $0.001 \$$ on average), mainly with an impact on land transformation.

For nuclear power, the results were between 0.001 (Brazil, Russia) and 0.007 $\$ / \mathrm{kWh}$ (South Korea). The impact is mainly due to the use of water $(38 \%)$, uranium $(12 \%)$, and chromium $(11 \%)$. These findings should be treated with caution, as our method does not include the impact of radioactive leaks/waste or the potential risk of nuclear incidents.

For solar power, the results were between 0.003 (Australia) and $0.017 \$ / \mathrm{kWh}$ (UK); the simpact were shown to be similar for open ground and roof installations. For roof-top installations, the contribution of metals is mainly from copper (12\%), gold (9.3\%), and aluminum (5.1\%).

Finally, for geothermal power, with emissions of carbon dioxide and air pollutants much lower than those of other technologies, the impacts were shown to be less than that of fossil-based electricity generation. An example to illustrate these results is provided for the UK in Figure 7. This country is a good example of the importance of resource scarcity as even though the inventory for the electricity generation from each type of energy is around in the average of the G20, the importance given to fossil and minerals resources for the UK in LIME3 was the highest among the G20 members in this study.

Figure 7 shows that the electricity generated using oil had the greatest impact, with a value of $0.240 \$ / \mathrm{kWh}$; this value is explained by the integration factor for oil, which is the highest in the G20. The UK has limited country reserves (2564 million barrels), and more than half of its crude oil imports are from Norway, whose oil reserves were also relatively small (6661). It can be also observed that coal has the second highest impact $(0.064 \$ / \mathrm{kWh})$ due to $\mathrm{CO}_{2}$ emissions and coal consumption (the UK has the fourth highest factor in the G20 due to its limited reserves). Solar energy showed a similar impact as natural gas due to the impact of minerals. The impact of geothermal-, hydro- (except for pumped storage for the same reasons as stated previously), nuclear-, and wind-power technologies was found to be low. 
0.25

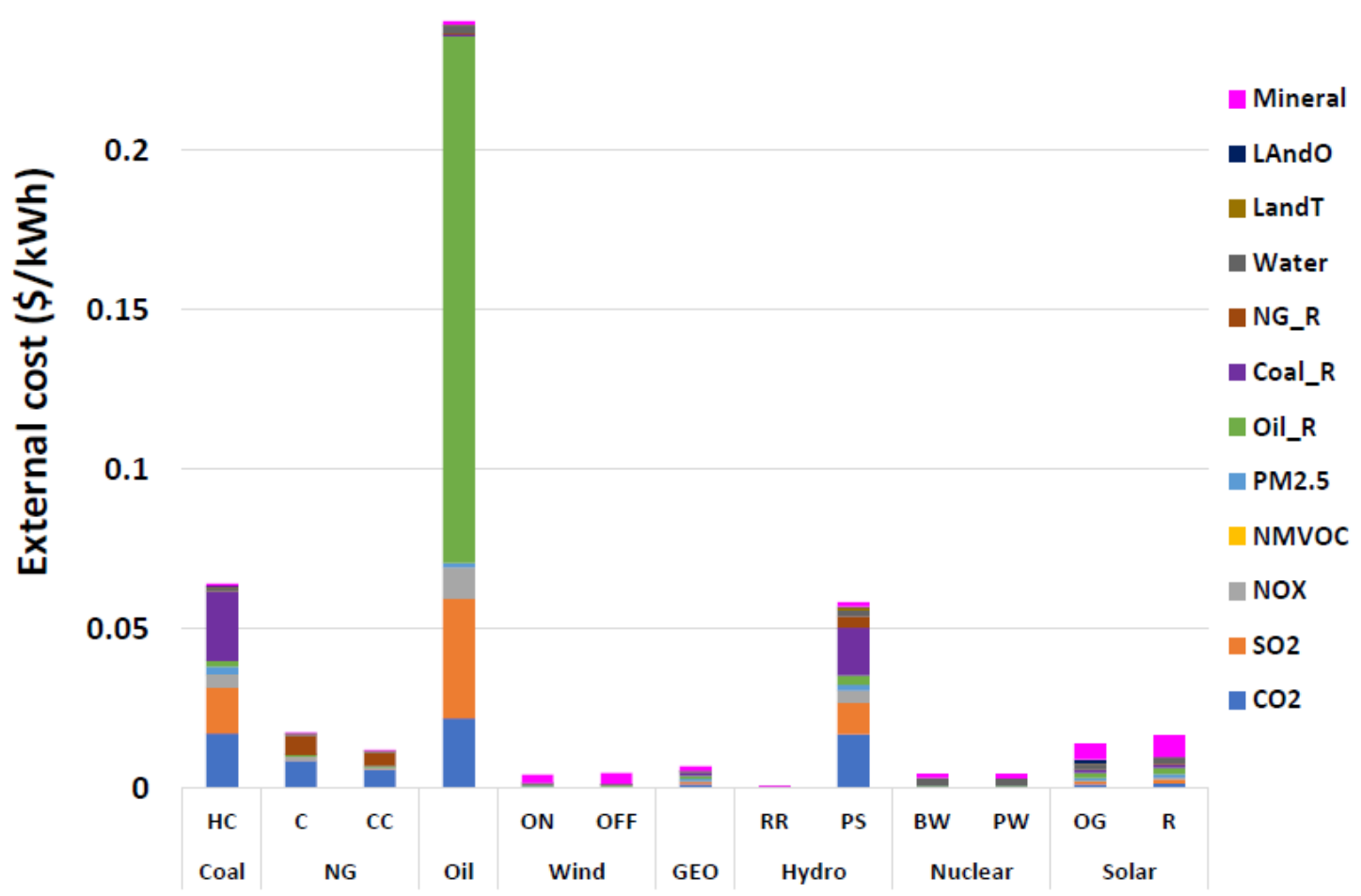

Figure 7. External cost of each technology in the UK for $1 \mathrm{kWh}$ generated by each technology.

\subsection{External Cost Estimation of Each Technology in G20 Countries}

It is then possible to explain the results for the power generation mix of each country. External cost were determined as detailed in Figure 8 . The results were estimated between $0.005 \$ / \mathrm{kWh}$ (France) and $0.172 \$ / \mathrm{kWh}$ (India). The nonweighted average result for the 19 countries was $0.044 \$ / \mathrm{kWh}$. As suggested by previous studies, the external cost is largely impacted by the dependence of a country on fossil-based energies. The results for each country are detailed in the following subsections.

Table 6 shows a summary of the results for each inventory item. It shows that the average values were the highest for carbon dioxide (0.012\$), PM2.5 (0.013\$), and, to a lesser extent, oil consumption $(0.003 \$)$, coal consumption $(0.002 \$)$, and land transformation $(0.001 \$)$. Standard deviation was found to be the highest for PM2.5 (0.027) and the lowest for NMVOC (0).

Table 6. Range of the external cost (\$) for each inventory item in G20 countries (average; SD).

\begin{tabular}{cc}
\hline $\mathrm{CO}_{2}$ & $0.001-0.026[0.012][0.006]$ \\
\hline $\mathrm{SO}_{2}$ & $0-0.020[0.005][0.006]$ \\
\hline $\mathrm{NOx}$ & $0-0.027[0.004][0.006]$ \\
\hline $\mathrm{NMVOC}$ & $0-0[0][0]$ \\
\hline PM2.5 & $0-0.089[0.013][0.027]$ \\
\hline Oil_R & $0-0.017[0.003][0.006]$ \\
\hline Coal_R & $0-0.015[0.002][0.004]$ \\
\hline Natural Gas_R & $0-0.004[0.001][0.001]$ \\
\hline Water & $0-0.006[0.001][0.001]$ \\
\hline Land transformation & $0-0.003[0.001][0.001]$ \\
\hline Land Occupation & $0-0.001[0.000][0]$ \\
\hline Mineral & $0.001-0.002[0.002][0]$ \\
\hline
\end{tabular}




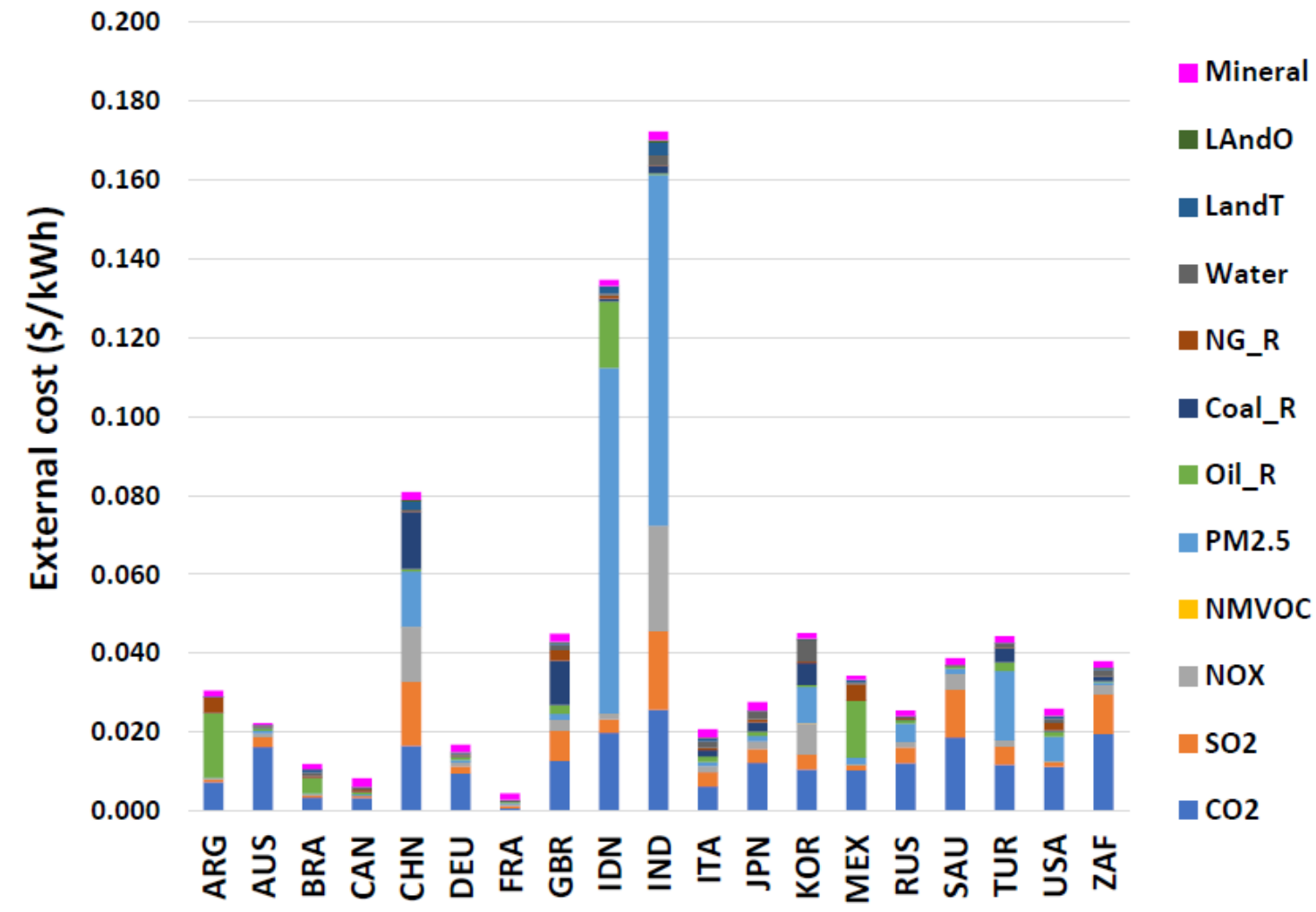

Figure 8. External cost of electricity generation for G20 countries ( $\$ / \mathrm{kWh})$.

\subsubsection{Argentina}

The external cost was determined to be $0.031 \$ / \mathrm{kWh}$ with the following main-impact distribution: oil (0.016\$), $\mathrm{CO}_{2}(0.007 \$)$, natural gas $(0.004 \$)$, mineral $(0.001 \$)$, and $\mathrm{SO}_{2}(0.001 \$)$.

The Argentinian mix in 2014 (see Section 2.2) was composed of the following technologies: coal $(3 \%)$, oil (14\%), natural gas (48\%), nuclear $(4 \%)$, hydro $(29 \%)$, solar/wind $(1 \%)$, and biofuel $(2 \%)$. The relatively low dependence on coal explains the lower impact of $\mathrm{CO}_{2}$ emissions and air pollution. Argentina relies more on oil than most G20 countries, and also produces much of its own oil, as highlighted in Figure 9. This resource being limited (2185 millions of barrels compared to 266,455 in Saudi Arabia or 80,000 in Russia), the social impact is higher than in other countries. The impact of natural gas is clearly explained by the fact that almost half of the electricity is generated using this resource.

\subsubsection{Australia}

The external cost was determined to be $0.022 \$ / \mathrm{kWh}$ with the following main impact distribution: $\mathrm{CO}_{2}(0.016 \$), \mathrm{SO}_{2}(0.002 \$), \operatorname{Nox}(0.001 \$), \mathrm{PM} 2.5$ (0.001\$), and oil (0.001\$).

The Australian mix in 2014 was composed of the following technologies: coal (61\%), oil (2\%), natural gas $(22 \%)$, hydro $(7 \%)$, solar/wind $(6 \%)$, and biofuel $(1 \%)$. The relatively high dependence on coal explains the higher impact of $\mathrm{CO}_{2}$ emissions. Australia has one of the lowest population densities in the world (3 pop $\left./ \mathrm{km}^{2}\right)$, so, despite this dependence on coal, the impact of air pollution on human heath in Australia was smaller than elsewhere. As Australian coal reserves are massive (Australia is the largest global coal exporter), the impact on the reserve was not high. 


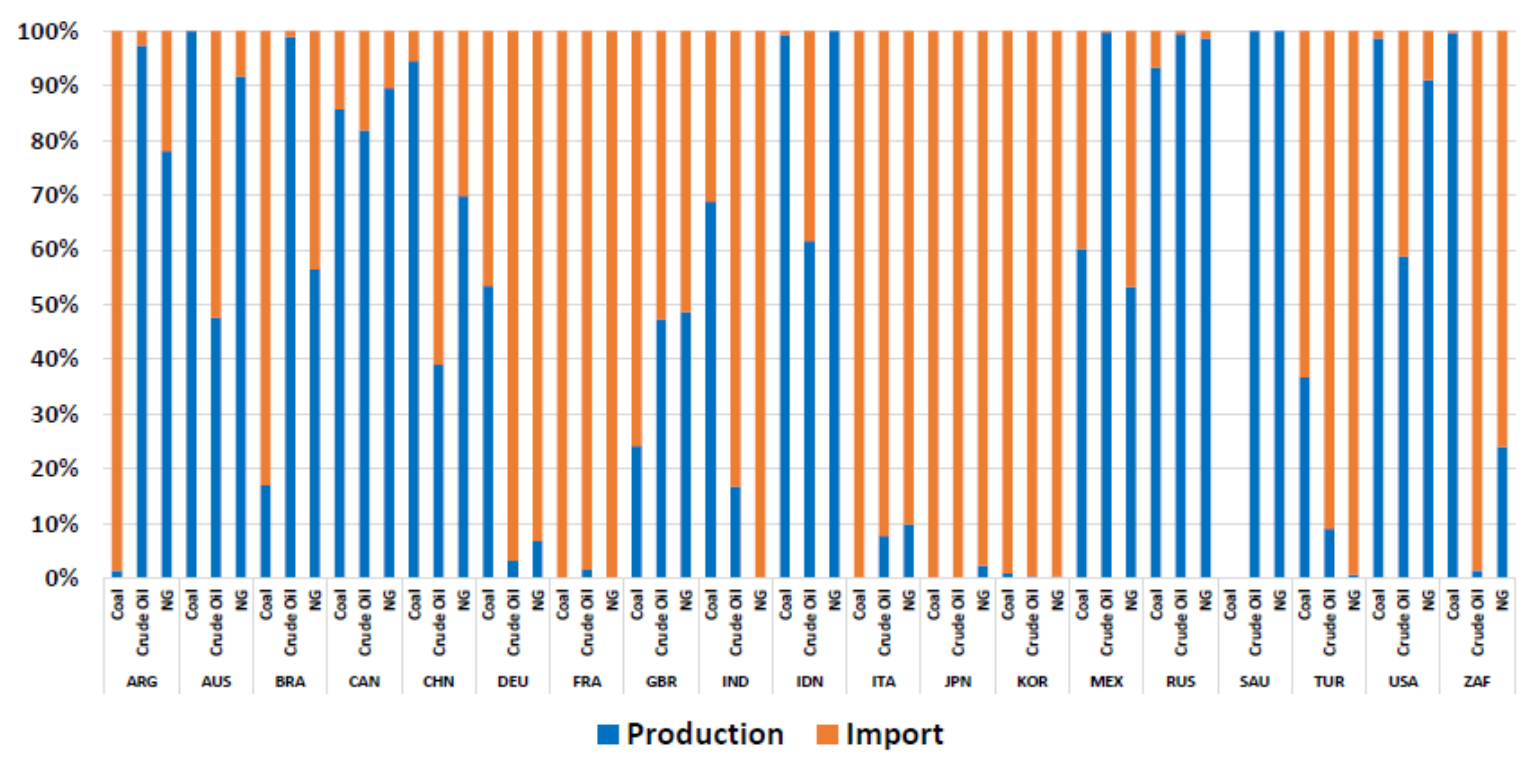

Figure 9. Production vs. importation for coal, oil, and natural gas in G20 countries [2].

\subsubsection{Brazil}

The external cost was determined to be $0.012 \$ / \mathrm{kWh}$ with the following main impact distribution: oil $(0.004 \$), \mathrm{CO}_{2}(0.004 \$)$, mineral $(0.001 \$)$, land tranformation $(0.001 \$)$, water $(0.001 \$)$, and natural gas $(0.001 \$)$.

The Brazilian mix in 2014 was composed of the following technologies: coal (5\%), oil (6\%), natural gas $(14 \%)$, nuclear $(3 \%)$, hydro (63\%), solar/wind $(2 \%)$, and biofuel $(8 \%)$. The relatively low-dependence on fossil fuels explains the low impact of $\mathrm{CO}_{2}$ emissions and air pollution. Brazil meets much of its own oil needs and has limited resources (12,999 million barrels), the same as Argentina; therefore, the impact of oil was shown to be slightly higher than that of other countries.

\subsubsection{Canada}

The external cost was determined to be $0.008 \$ / \mathrm{kWh}$ with the following main impact distribution: $\mathrm{CO}_{2}(0.003 \$)$, mineral $(0.002 \$)$, water $(0.001 \$)$, natural gas $(0.001 \$)$, and oil $(0.001 \$)$.

The Canadian mix in 2014 was composed of the following technologies: coal (10\%), oil (1\%), natural gas $(9 \%)$, nuclear $(16 \%)$, hydro $(58 \%)$, solar/wind $(4 \%)$, and biofuel $(1 \%)$. The country's relativvely low dependence on fossil fuels explains the low impact of its $\mathrm{CO}_{2}$ emissions and air pollution.

\subsubsection{China}

The external cost was determined to be $0.081 \$ / \mathrm{kWh}$ with the following main impact distribution: $\mathrm{CO}_{2}(0.017 \$), \mathrm{SO}_{2}(0.016 \$)$, coal $(0.015 \$), \mathrm{PM} 2.5(0.014 \$)$, Nox $(0.014 \$)$, mineral $(0.002 \$)$, land transformation $(0.002 \$)$, and oil (0.001\$).

The Chinese mix in 2014 was composed of the following technologies: coal (72\%), natural gas $(2 \%)$, nuclear $(2 \%)$, hydro $(19 \%)$, solar/wind $(3 \%)$, and biofuel $(1 \%)$. The high dependence on coal explains the large impact of $\mathrm{CO}_{2}$ emissions and air pollution, which is amplified by the country's high population density in urban areas. China is also exploiting its own coal, mainly using it to generate electricity, so the impact on the reserve was quite significant.

\subsubsection{France}

The external cost was determined to be the lowest at $0.005 \$ / \mathrm{kWh}$ with the following main impact distribution: mineral (0.002\$), $\mathrm{CO}_{2}(0.001 \$)$, and $\mathrm{SO}_{2}(0.001 \$)$. 
The French mix in 2014 was composed of the following technologies: coal ( $2 \%)$, natural gas ( $2 \%)$, nuclear $(78 \%)$, hydro $(12 \%)$, solar/wind $(4 \%)$, and biofuel $(1 \%)$. The high dependence on nuclear power explains the absence of damage for all inventory items. However, as highlighted previously, these findings should be interpreted with extreme caution, given that our method does not include the damage caused by radioactive waste or the possible damage risk due to leakages or accidents from nuclear-power plants (as seen, for example, in Japan following the 2011 Tohoku earthquake and tsunami).

\subsubsection{Germany}

The external cost was determined to be $0.017 \$ / \mathrm{kWh}$ with the following main impact distribution: $\mathrm{CO}_{2}(0.010 \$)$, mineral $(0.002 \$), \mathrm{SO}_{2}(0.002 \$)$, Nox $(0.001 \$)$, oil $(0.001 \$)$, and PM2.5 (0.001\$).

The German mix in 2014 was composed of the following technologies: coal (44\%), oil (1\%), natural gas $(10 \%)$, nuclear $(15 \%)$, hydro $(4 \%)$, solar/wind $(15 \%)$, and biofuel $(9 \%)$. The country's high dependence on coal energy explains more than half of the total external cost. However, as stated previously, the impact of coal is the lowest in the G20 due to the low emissions of airborne substances from coal-power plants.

\subsubsection{India}

The external cost was determined to be the highest at $0.172 \$ / \mathrm{kWh}$ with the following mainimpact distribution: PM2.5 (0.089\$), Nox (0.027\$), $\mathrm{CO}_{2}(0.026 \$), \mathrm{SO}_{2}(0.020 \$)$, land transformation (0.003\$), water $(0.003 \$)$, mineral $(0.002 \$)$, and coal $(0.002 \$)$.

The Indian mix in 2014 was composed of the following technologies: coal $(69 \%)$, oil (2\%), natural gas $(5 \%)$, nuclear $(3 \%)$, hydro, $(10 \%)$, solar/wind $(1 \%)$, and biofuel $(1 \%)$. Similar to China, the high dependence on coal explains the large impact of $\mathrm{CO}_{2}$ emissions and air pollution. The higher population density (four times higher on average than other G20 countries) as well as higher emissions of particulate matter are the reasons why the impact of air pollution was much higher in India than in China.

\subsubsection{Indonesia}

Th external cost was determined to be the second highest at $0.135 \$ / \mathrm{kWh}$ with the following main impact distribution: PM2.5 (0.088\$), $\mathrm{CO}_{2}(0.020 \$)$, oil (0.017\$), $\mathrm{SO}_{2}(0.003 \$)$, land transformation $(0.002 \$)$, mineral $(0.002 \$)$, Nox $(0.001 \$)$, natural gas $(0.001 \$)$, and coal $(0.001 \$)$.

The Indonesian mix in 2014 was composed of the following technologies: coal (53\%), oil (10\%), natural gas (23\%), hydro (7\%), and geothermal (4\%). Similar to China and India, the high dependence on coal explains the large impact of $\mathrm{CO}_{2}$ emissions and air pollution. The impact caused by particulate matter was high due to the heavy particulate-matter emissions from the use of lignite: when $1 \mathrm{kWh}$ of electricity was produced in Indonesia, $21 \mathrm{~g}$ of PM2.5 were emitted on average (compared to $2.5 \mathrm{~g}$ in India and $0.5 \mathrm{~g}$ in China).

\subsubsection{Italy}

The external cost was determined to be $0.021 \$ / \mathrm{kWh}$ with the following main-impact distribution: $\mathrm{CO}_{2}(0.006 \$), \mathrm{SO}_{2}(0.004 \$)$, mineral $(0.002 \$)$, water $(0.002 \$)$, coal $(0.002 \$)$, Nox $(0.001 \$)$, oil $(0.001 \$)$, PM2.5 (0.001\$), land transformation (0.001\$), and natural gas $(0.001 \$)$.

External cost was determined at $0.043 \$ / \mathrm{kWh}$. The Italian mix in 2014 was composed of the following technologies: coal (17\%), oil ( $5 \%)$, natural gas (33\%), hydro (22\%), geothermal $(2 \%)$, solar/wind $(14 \%)$, and biofuel (8\%). The relatively low dependence on coal explained the lower impact of $\mathrm{CO}_{2}$ emissions and air pollution. 


\subsubsection{Japan}

Th external cost was determined to be $0.028 \$ / \mathrm{kWh}$ with the following main impact distribution: $\mathrm{CO}_{2}(0.012 \$), \mathrm{SO}_{2}(0.004 \$)$, coal $(0.002 \$)$, mineral $(0.002 \$)$, water $(0.002 \$)$, Nox $(0.002 \$)$, PM2.5 (0.001\$), oil $(0.001 \$)$, and natural gas $(0.001 \$)$.

The Japanese mix in 2014 was composed of the following technologies: coal (34\%), oil (11\%), natural gas $(40 \%)$, hydro $(8 \%)$, solar/wind $(3 \%)$, and biofuel $(3 \%)$. The relatively high dependence on fossil fuels explains more than half of the total external cost due to $\mathrm{CO}_{2}$ emissions and air pollution.

\subsubsection{Mexico}

Th external cost was determined to be $0.034 \$ / \mathrm{kWh}$ with the following main impact distribution: oil (0.014\$), $\mathrm{CO}_{2}(0.010 \$)$, natural gas $(0.004 \$), \mathrm{PM} 2.5(0.002 \$), \mathrm{SO}_{2}(0.001 \$)$, mineral $(0.001 \$)$, and land transformation $(0.001 \$)$.

The Mexican mix in 2014 was composed of the following technologies: coal (11\%), oil (11\%), natural gas $(57 \%)$, nuclear $(3 \%)$, hydro $(13 \%)$, geothermal $(2 \%)$, and solar/wind $(3 \%)$. For the same reason as Argentina and Brazil, the use of oil to generate electricity directly impacted the national reserves and increased the impact compared to other countries (Mexico produced nearly $100 \%$ of its own oil). The country's low dependence on coal explained the lower impact caused by carbon dioxide and air pollution. Its higher dependence on natural gas explained the rest of the cost.

\subsubsection{Russia}

The external cost was determined to be $0.026 \$ / \mathrm{kWh}$ with the following main impact distribution: $\mathrm{CO}_{2}(0.012 \$), \mathrm{PM} 2.5(0.005 \$), \mathrm{SO}_{2}(0.004 \$)$, Nox $(0.001 \$)$, mineral $(0.001 \$)$, and oil $(0.001 \$)$.

The Russian mix in 2014 was composed of the following technologies: coal (15\%), oil (1\%), natural gas $(50 \%)$, nuclear $(17 \%)$, and hydro (17\%). The relativelly high dependence on fossil fuels explains most of the result, but as Russia has important fossil reserves, the impact was mitigated for resource consumption. The impact related to air pollution was low because of the lower population density.

\subsubsection{Saudi Arabia}

The external cost was determined to be $0.039 \$ / \mathrm{kWh}$ with the following main impact distribution: $\mathrm{CO}_{2}(0.019 \$), \mathrm{SO}_{2}(0.012 \$)$, Nox $(0.004 \$)$, mineral (0.002\$), PM2.5 (0.001\$), and oil (0.001\$).

The Saudi Arabian mix in 2014 was composed of the following technologies: oil (49\%) and natural gas (51\%). The country's sole dependence on oil and natural gas explained most of the result. Despite having large reserves, the country's substantial use of oil still had an impact.

\subsubsection{South Africa}

The external cost was determined to be $0.038 \$ / \mathrm{kWh}$ with the following main impact distribution: $\mathrm{CO}_{2}(0.020 \$), \mathrm{SO}_{2}(0.010 \$)$, Nox $(0.002 \$)$, water $(0.002 \$)$, mineral $(0.002 \$)$, coal $(0.001 \$)$, and PM2.5 (0.001\$).

The South African mix in 2014 was composed of the following technologies: coal (92\%), nuclear $(5 \%)$, and hydro (2\%). Most of the total external cost was explained by the very high reliance on coal, but as population density was not significant, the potential impact was shown to be less than that in Asian countries.

\subsubsection{South Korea}

The external cost was determined at $0.045 \$ / \mathrm{kWh}$ with the following main-impact distribution: $\mathrm{CO}_{2}$ (0.011\$), PM2.5 (0.009\$), Nox $(0.008 \$)$, water $(0.006 \$)$, coal $(0.005 \$), \mathrm{SO}_{2}(0.004 \$)$, and mineral $(0.001 \$)$.

The South Korean mix in 2014 was composed of the following technologies: coal (42\%), oil (3\%), natural gas (24\%), nuclear (28\%), hydro (1\%), and solar/wind $(1 \%)$. The relatively high dependence on fossil fuels explained more than half of the total external cost due to $\mathrm{CO}_{2}$ emissions and air 
pollution. The impact of coal was explained by the fact that Korea mainly relies on coal imports from other countries, and one-third of these imports is from Indonesia [59], a country with extensive coal extraction.

\subsubsection{Turkey}

Th external cost was determined to be $0.044 \$ / \mathrm{kWh}$ with the following main impact distribution: PM2.5 (0.018\$), $\mathrm{CO}_{2}(0.012 \$), \mathrm{SO}_{2}(0.005 \$)$, coal $(0.004 \$)$, oil $(0.002 \$)$, mineral $(0.002 \$)$, Nox $(0.002 \$)$, and water $(0.001 \$)$.

The Turkish mix in 2014 was composed of the following technologies: coal (30\%), oil (1\%), natural gas $(48 \%)$, hydro (16\%), geothermal (1\%), and solar/wind (3\%). The high dependence on fossil fuels explained more than half of the total external costs due to $\mathrm{CO}_{2}$ emissions and air pollution. The impact of coal was explained by the fact that Turkey produces about one-third of its own needs, but the country's reserve decreased every year (its integration factor was the second highest among the G20 countries after Indonesia).

\subsubsection{UK}

Th external cost was determined to be $0.045 \$ / \mathrm{kWh}$ with the following impact distribution: $\mathrm{CO}_{2}$ (0.013\$), coal $(0.011 \$), \mathrm{SO}_{2}(0.008 \$)$, Nox $(0.003 \$)$, natural gas $(0.003 \$)$, oil $(0.002 \$)$, mineral $(0.002 \$)$, PM2.5 (0.001\$), water (0.001\$), and land transformation (0.001\$).

The UK mix in 2014 was composed of the following technologies: coal (30\%), natural gas (30\%), nuclear $(19 \%)$, hydro $(3 \%)$, solar/wind $(11 \%)$, and biofuel $(8 \%)$. The relatively high dependence on fossil fuels explained one-quarter of the total external costs due to $\mathrm{CO}_{2}$ emissions and air pollution. The impact of coal was explained by the country's lower coal reserves compared to other producers.

\subsubsection{USA}

The external cost was determined to be $0.026 \$ / \mathrm{kWh}$ with the following main impact distribution: $\mathrm{CO}_{2}(0.011 \$), \mathrm{PM} 2.5(0.006 \$), \mathrm{NG}(0.002 \$)$, mineral (0.002\$), oil (0.001\$), $\mathrm{SO}_{2}(0.001 \$)$, water $(0.001 \$)$, and land transformation $(0.001 \$)$.

The USA mix in 2014 was composed of the following technologies: coal (39\%), oil (1\%), natural gas $(27 \%)$, nuclear (19\%), hydro (6\%), solar/wind (5\%), and biofuel $(2 \%)$. The relatively high-dependence on fossil fuels explained more than half of the total external costs due to $\mathrm{CO}_{2}$ emissions and air pollution.

\section{Discussion}

\subsection{Estimation of the Annual GDP Loss}

The product of the annual electricity generated with the external price per $\mathrm{kWh}$ (calculated previously) enabled us to estimate the total annual external cost of electricity generation. The data provided annually by Enerdata (Global Energy Statistical Yearbook 2019) [5] were used as presented in Table A7.

The values were found to be between 2.9 billion \$ (France) and 574 billon \$ (China). This clearly indicates that governments should push for the development of renewable energy sources and energy-saving policies.

GDP loss due to electricity generation was then calculated for each country, as detailed in Table 7. 
Table 7. Annual external cost and potential GDP loss ratio due to annual electricity generation.

\begin{tabular}{ccc}
\hline Country & Annual External Cost (Bill USD) & Potential GDP (Nominal) Loss Ratio \\
\hline Argentina & 4.6 & $0.88 \%$ \\
\hline Australia & 5.7 & $0.40 \%$ \\
\hline Brazil & 7.2 & $0.38 \%$ \\
\hline Canada & 5.3 & $0.31 \%$ \\
\hline China & 574 & $4.22 \%$ \\
\hline France & 2.9 & $0.10 \%$ \\
\hline Germany & 11.0 & $0.28 \%$ \\
\hline India & 282 & $10.37 \%$ \\
\hline Indonesia & 36.2 & $3.47 \%$ \\
\hline Italy & 6.1 & $0.29 \%$ \\
\hline Japan & 30.9 & $0.62 \%$ \\
\hline Mexico & 10.9 & $0.89 \%$ \\
\hline Russia & 29.3 & $1.77 \%$ \\
\hline Saudi Arabia & 13.7 & $1.75 \%$ \\
\hline South Africa & 9.7 & $2.64 \%$ \\
\hline South Korea & 26.7 & $1.65 \%$ \\
\hline Turkey & 13.3 & $1.74 \%$ \\
\hline UK & 15.0 & $0.53 \%$ \\
\hline USA & 115 & $0.56 \%$ \\
\hline
\end{tabular}

Again, the impact in newly industrialized countries was the most important, estimated to be up to $10.4 \%$ of India's GDP. The impact was less than $1 \%$ in major developed countries except for South Korea (1.65\%).

\subsection{Comparison of Electricity External Price with Market Price}

In this section, the external price of electricity was compared to the market price of electricity [60], and the results are presented in Figure 10.

By comparing these two indicators it was possible to identify which countries could provide cheap electricity while still saving environmental quality. On the other hand, this comparison also highlights the countries that generate a low-cost electricity with a high environmental burden. As expected, a trend could again be delimited between developed and newly industrialized countries. In India and Indonesia, the ratio of external cost and market price was 2.3 and 1.7, respectively. This ratio was also shown to be higher for Turkey and Mexico (0.4-0.5). In contrast, this ratio was less than 0.2 on average for developed countries, partly due to their higher reliance on renewables.

Another conclusion can be made for India, Indonesia, and China: developing countries often rely on fossil energy as it is cheaper to generate electricity with it. However, our comparison showed that it was still possible to produce energy at a lower cost even with renewables as the main energy source. Canada is a very good example: both its market price and external costs are lower than those of other developed countries because of its use of hydropower. The high water scarcity in India, Indonesia, and China likely led to their higher reliance on natural gas. Following the example of Mexico could be their best option to reduce the environmental impact. 


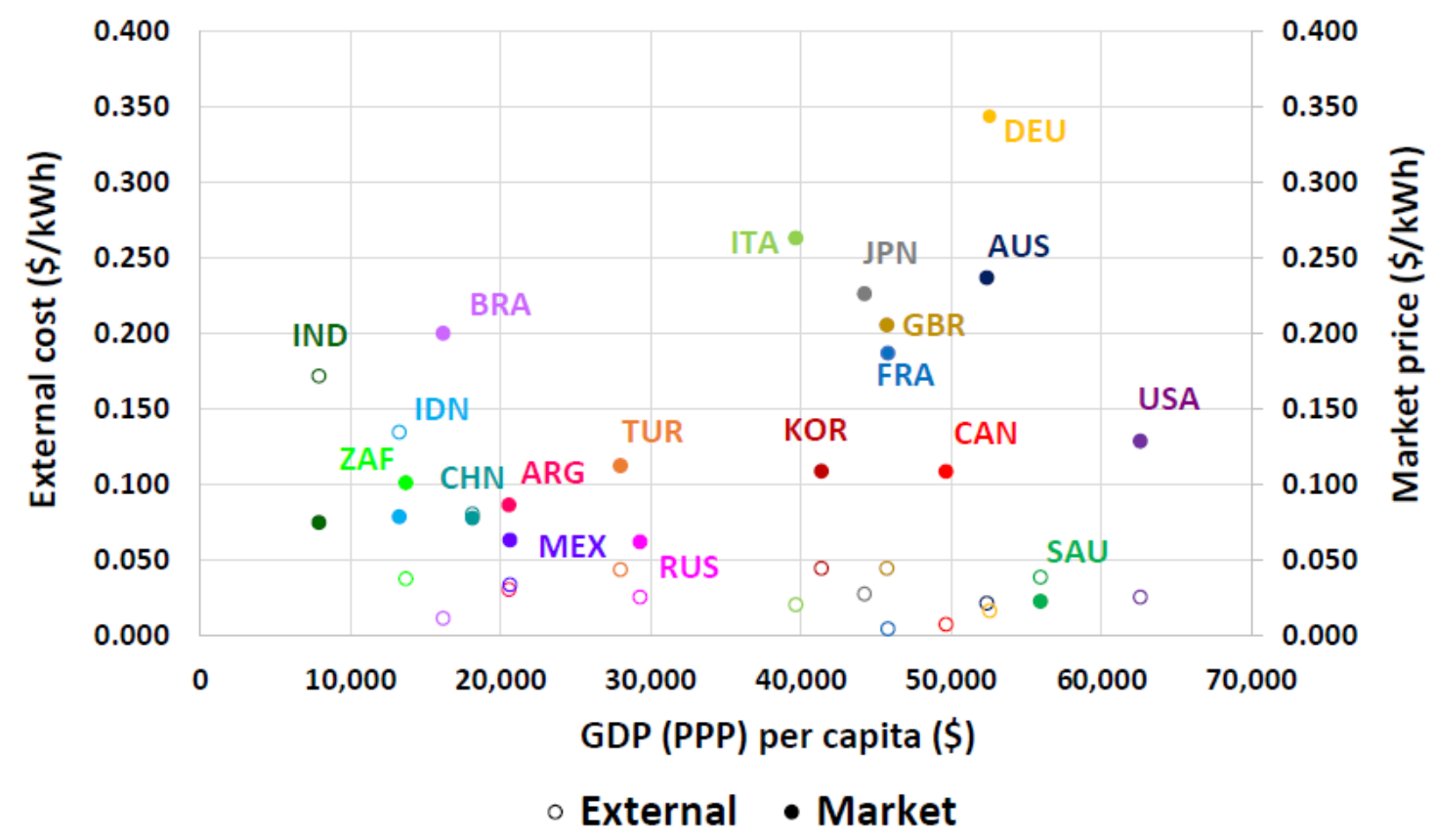

Figure 10. Market price and external cost variation with GDP (PPP) per capita of G20 countries.

\subsection{Comparison with Previous Studies}

Despite the differences in the method and inventory (Table 8), our results were comparable to those of to the study conducted by the EEA for four countries: France, Germany, Italy, and the UK. For France, the external cost for $1 \mathrm{kWh}$ of generated electricity was estimated to be between 0.008 (low estimation) and 0.021 (high estimation); for Germany, it was between 0.023 and $0.085 \$$; for Italy, it was between 0.017 and $0.062 \$$; and, for the UK, it was between 0.026 and $0.070 \$$. As described in Section 3.1, in this study, external costs were 0.005, 0.017, 0.021, and $0.045 \$$ for these countries, respectively. Therefore, the trend observed in both studies is similar.

For France, the power generation mix was almost the same in 2005 and 2014 (with the nuclear share between $75 \%$ and $80 \%$ of the mix), and the external cost for the electricity generated using nuclear power in our study was also half (0.002 vs. $0.004 \$)$; this could explain why our result for France was two times lower than the EEA's lowest estimation results.

For Germany, the nuclear share was reduced by almost half between 2005 and 2014 for renewables. Moreover, the impact of coal was estimated to be lower in our research (0.021-0.027 vs. 0.050-0.080), likely due to efficiency improvements in the last 10 years. Our results were close to the lowest estimations of the EEA methodology.

For Italy, the share of oil decreased from 15\% to 5\% between 2005 and 2014 for natural gas. The impact of natural gas was not very different between both studies (0.020-0.030 vs. $0.011-0.019$ in our study). Our results were still higher than the lowerest estimations in the EEA study due to our consideration of a larger number of impact types.

For the UK, the energy mix has also not drastically changed since 2005. The impact of natural gas was very similar in both studies $(0.010-0.020$ vs. $0.012-0.017$ in our study). This is likely due probably to the impact of coal consumption (0.011\$). Thus, our results agreed with the middle values of the EEA estimations.

It is clear that our study had some similarities with the EEA study, which can be explained by the fact that both studies showed climate change and air pollution to have the greatest important impact. For France, Germany, and Italy, our results were close to the EEA's lowest estimations, but for the UK, the addition of resource scarcity in our method was probably the main reason why our results were two times higher than the lowest estimations of the EEA, which justified the framework and method chosen in our study. Additionaly, ihe EEA study was conducted in 2005, whereas in this study 2014 
data were used. Thus, it is possible that, by applying the EEA methodology to more current data, the results might be estimated to be lower than ours. Indeed, EEA research has shown that, between 1990 and 2005, the external cost of the power generation mix in these four countries was reduced by $70 \%$ on average. One of the reasons for this reduction is the increasing share of renewables in the power generation mix. In Germany, the share of renewables increased from $4 \%$ to about $10 \%$ between 1990 and 2005, and from $10 \%$ to about $30 \%$ in 2016 . The thermal efficiency of power plants is another important reason. In the EU28, the maximum efficiency achieved for thermal power plants was around $42 \%$ in $1990,47 \%$ in 2005 , and approximatively $50 \%$ in 2015 [61].

Table 8. Comparison of the European Environment Agency (EEA) study and this study.

\begin{tabular}{ccc}
\hline & EEA & This Study \\
\hline & Main parameters & \\
\hline Area of interest & EU & G20 \\
\hline Dataset (year) & 2005 & 2014 \\
\hline Currency & Euro & Dollar \\
\hline Climate change & $\mathrm{x}$ & \\
\hline Air pollution & $\mathrm{x}$ & $\mathrm{x}$ \\
\hline Photochemical ozone & & $\mathrm{x}$ \\
\hline Water use & & $\mathrm{x}$ \\
\hline Fossil fuels & & $\mathrm{x}$ \\
\hline Mineral resources & $\mathrm{x}$ & $\mathrm{x}$ \\
\hline Land use & & \\
\hline Noise & $0.026-0.085$ & \\
\hline France & $0.008-0.021$ & 0.005 \\
\hline Germany & $0.023-0.085$ & 0.017 \\
\hline Italy & 0.062 & 0.021 \\
\hline UK & &
\end{tabular}

\section{Conclusions}

The aim of this research was to evaluate the external cost of electricity generation in G20 countries using the LIME3 global lifecycle impact assessment (LCIA) method. External costs are an interesting indicator that can help decision makers determine which energy sources to prioritize based on the direct emissions from plants alongside the impact of the supply, including the consideration of the trade structure.

It can be confirmed that the share of fossil fuels in the electricity mix of a country is the main parameter that influences the external cost of electricity generation due to climate change and air pollution impacts. Countries such as India (76\% of electricity generated through fossil fuels), Indonesia $(86 \%)$, and China $(74 \%)$ showed the highest estimated costs at $0.172,0.135$, and $0.081 \$ / \mathrm{kWh}$, respectively. In a similar vein, countries with the highest renewable share had the lowest results: Canada $(62 \%)$ and Brazil (65\%) were 0.008 and $0.012 \$ / \mathrm{kWh}$, respectively.

This study considered the full life-cycle of electricity, as well as a large range of impact categories at a global scale. The results confirmed the suitability of the method, as oil-based electricity, due to oil resource consumption, had the highest external cost on average (0.105 $\$ / \mathrm{kWh})$. The external cost of 
solar and wind power was also mostly explained by resource consumption, and the external cost of hydropower was high in some locations due to water scarcity (India: $0.068 \$ / \mathrm{kWh}$ ).

Several indicators were provided for decision makers: to support again the need to switch quickly from fossil energies to renewables, to improve efficiency of power plants, to relocate fossil power pants further from populated areas, and to impletement emission control technologies for thermal power plants. However, one additional point should be raised: when switching to renewables, it is necessary to consider the scarcity of resources and, if those resources are imported, the situation at the origin of the imports. Different locations require different strategies.

In the future it would be profitable for LCA researchers to provide an assessment for developing countries, for which studies are still rare. As such information is largely missing at the moment, it is also imperative to collect reliable inventory data concerning the resource consumption and emissions of power-plants in developing countries. A type of LIME3 weighting method based on the willingness to pay among G20 countries could also be developed for developing countries.

Author Contributions: Conceptualization, S.K. and N.I.; methodology, S.K. and N.I.; software, S.K. and Y.I.; formal analysis, S.K. and N.I.; investigation, S.K., A.A. and N.I.; writing-original-draft preparation, S.K.; supervision, N.I. All authors have read and approved the final manuscript.

Funding: This research received no external funding.

Conflicts of Interest: The authors declare no conflict of interest.

\section{Appendix A}

Table A1. List of used acronyms.

\begin{tabular}{|c|c|}
\hline ARG & Argentina \\
\hline AUS & Australia \\
\hline BRA & Brazil \\
\hline Bio-CCS & Biomass with carbon capture and storage \\
\hline CAN & Canada \\
\hline CCS & Carbon capture and storage \\
\hline $\mathrm{CHN}$ & China \\
\hline Coal_R & Coal Resource \\
\hline DALY & Disability-adjusted life year \\
\hline DEU & Germany \\
\hline DF & Damage factor \\
\hline $\mathrm{EC}$ & External cost \\
\hline EEA & European Environment Agency \\
\hline EINES & Expected increase in number of extinction species \\
\hline EV & Economic-value conversion factor \\
\hline EU & European Union \\
\hline FRA & France \\
\hline GBR & United Kingdom \\
\hline GDP & Gross Domestic Production \\
\hline IDN & Indonesia \\
\hline IEA & International Energy Agency \\
\hline IND & India \\
\hline
\end{tabular}


Table A1. Cont.

\begin{tabular}{|c|c|}
\hline IF & Integration Factor \\
\hline ISO & International Organization for Standardization \\
\hline ITA & Italy \\
\hline JPN & Japan \\
\hline KOR & Korea \\
\hline LandT & Land Transformation \\
\hline LandO & Land Occupation \\
\hline LCA & Life-cycle assessment \\
\hline LCI & Life-cycle inventory \\
\hline LCIA & Life-cycle impact assessment \\
\hline LIME & Life-cycle impact-assessment method based on endpoint modeling \\
\hline MEX & Mexico \\
\hline NG & Natural Gas \\
\hline NG_R & Natural Gas Resource \\
\hline Oil_R & Oil Resource \\
\hline PPP & Purchasing Power Parity \\
\hline SAU & Saudi Arabia \\
\hline SD & Standard Deviation \\
\hline TUR & Turkey \\
\hline USA & United States \\
\hline WTP & Willingness to pay \\
\hline $\mathrm{ZAF}$ & South Africa \\
\hline$\$$ & US dollars \\
\hline
\end{tabular}

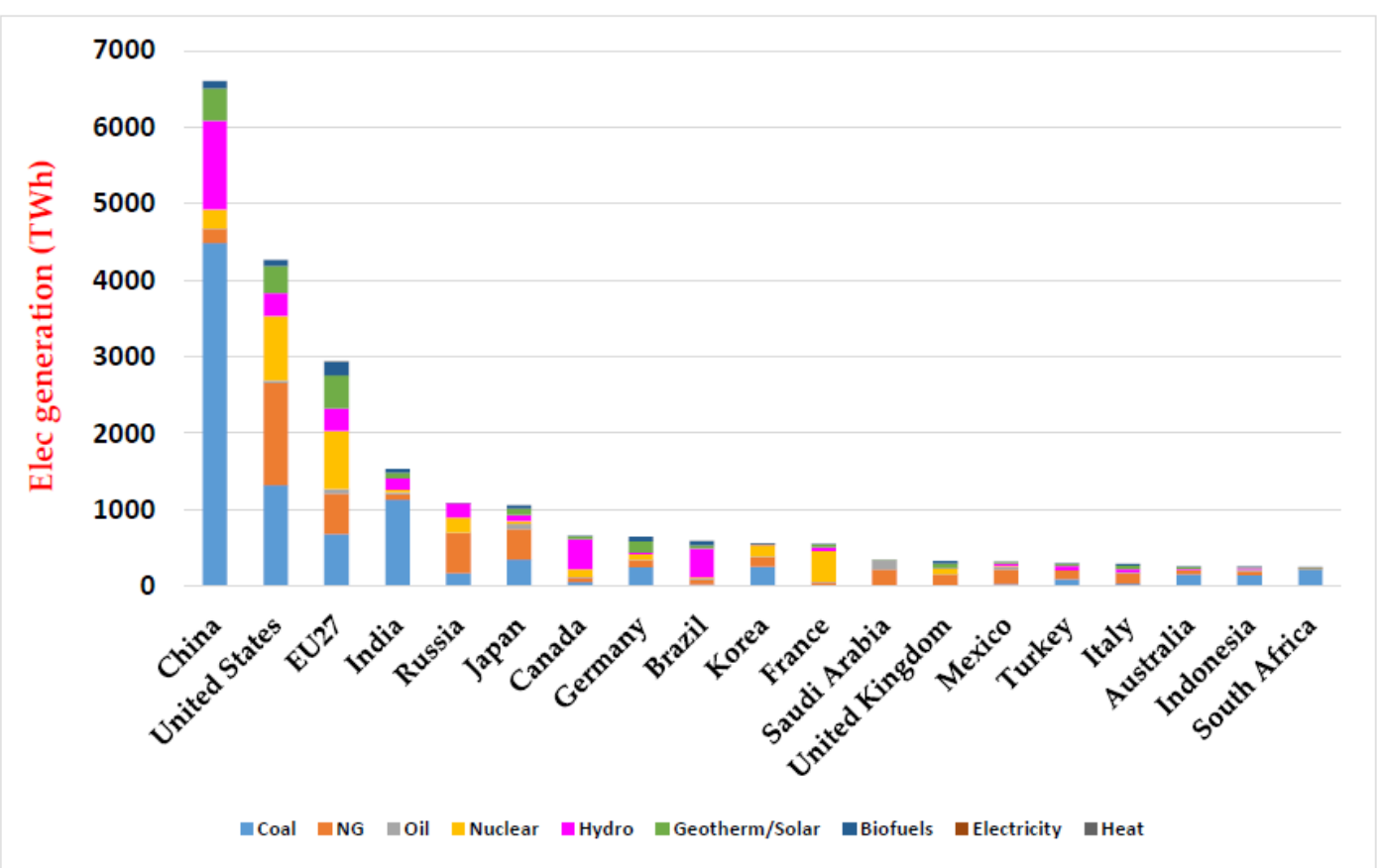

Figure A1. Electricity generation in G20 countries (2017 data). 
Table A2. Non-exhaustive findings of the life-cycle assessment (LCA) studies concerning electricity generation published during the period 2019-2020 (up to February 2020).

\begin{tabular}{|c|c|c|}
\hline Coal & $\begin{array}{l}- \\
-\end{array}$ & $\begin{array}{l}\text { Zhu et al., } 2020 \text { [14]: The water footprint of coal-fired power generation in China was } \\
\text { evaluated: } 6.60 \mathrm{~m}^{3} / \mathrm{MWh} \text { with } 24.8 \% \text { for the blue water footprint and } 75.2 \% \text { for the } \\
\text { grey water footprint. Even though Northwest China has water scarcity, it is the main } \\
\text { region providing coal-fired power in the country. } \\
\text { Young et al., } 2019 \text { [62]: Evaluation of the possible carbon reduction while using } \\
\text { amine solvent-based carbon capture systems based on monoethanolamine (MEA) in } \\
\text { the USA. The reduction was estimated at } 70 \% \text { for coal power plants (subcritical and } \\
\text { super critical coal power plants) in comparison with the systems without CCS } \\
\text { however one of the drawbacks is the increase of water consumption (about } 60 \% \text { ) due } \\
\text { to the cooling load incurred by the carbon capture unit. } \\
\text { Yu et al., } 2019 \text { [63]: LCA of transforming (partly or completely) a subcritical power } \\
\text { plant into a polygeneration plant. In the complete transformation scenario: the } \\
\text { impacts ( } 759.8 \mathrm{~kg} \text { CO }{ }_{2} \text { eq/MWh) were found lower than the best technologies } \\
\text { available for coal power plants: ultra-supercritical (USC; } 801 \mathrm{~kg} \mathrm{CO}_{2} \text { eq/MWh) and } \\
\text { integrated coal gasification combined cycle (IGCC; } 813 \mathrm{~kg} \mathrm{CO} \mathrm{CO}_{2} \text { eq/MWh). Compared } \\
\text { with the original sub-critical power plant, the complete transformation can reduce } \\
\text { greenhouse gas emissions by } 36.5 \% \text {. }\end{array}$ \\
\hline Natural gas & - & $\begin{array}{l}\text { Young et al., } 2019 \text { [62]: Evaluation of the possible carbon reduction while using } \\
\text { amine solvent-based carbon capture systems based on monoethanolamine (MEA) in } \\
\text { the USA. The reduction was estimated at } 63 \% \text { for natural gas combined cycle (NGCC) } \\
\text { power plant in comparison with the systems without CCS however one of the } \\
\text { drawbacks is the increase of water consumption (about } 60 \% \text { ) due to the cooling load } \\
\text { incurred by the carbon capture unit. } \\
\text { Tarannum et al., } 2019 \text { [64]: LCA of natural gas combined cycle power plant in } \\
\text { Bangladesh: the GWP was } 464 \mathrm{~g} \mathrm{CO} 2 \mathrm{eq} / \mathrm{kWh} \text { with } 71 \% \text { of the impact due to the } \\
\text { electricity generation and } 20 \% \text { due to the transportation of the fuel. }\end{array}$ \\
\hline Oil & - & $\begin{array}{l}\text { Tarannum et al., } 2019 \text { [64]: LCA of heavy fuel oil power plant in Bangladesh: the } \\
\text { GWP was } 831 \mathrm{~g} \mathrm{CO}_{2} \text { eq/kWh with } 88 \% \text { of the impact due to the electricity generation } \\
\text { and } 11 \% \text { due to the transportation of the fuel. }\end{array}$ \\
\hline Wind & - & $\begin{array}{l}\text { Xie et al., } 2020 \text { [65]: Three types of wind turbines were evaluated in China, the } \\
\text { average } \mathrm{CO}_{2} \text { emission was } 3.9 \mathrm{~g} / \mathrm{kWh} \text { mainly impacted by manufacturing and } \\
\text { decommissioning stages; The average energy input was } 0.0625 \mathrm{MJ} / \mathrm{kWh} \text {. } \\
\text { Kouloumpis et al., } 2020 \text { [66]: A real case of small wind turbine is evaluated in Poland. } \\
\text { The results were found around } 55 \mathrm{~g} \mathrm{CO}_{2} / \mathrm{kWh} \text { and } 2920 \mathrm{~g} \mathrm{CO}_{2} / \mathrm{kWh} \text { depending on } \\
\text { whether or not the components are treated after the end of life, the low wind speed } \\
\text { affecting the results. If excluding the end-of-life stage, the } \mathrm{GWP} \text { impact was shared } \\
\text { between the foundation ( } 30.9 \%) \text {, the mast ( } 30.9 \% \text { ) and turbine components }(29.7 \% \text { ). } \\
\text { Besseau et al., } 2019 \text { [67]: A focus on a wind turbine fleet in Denmark. The tool } \\
\text { developed (generating more than } 10,000 \text { cradle-to-grave life cycle inventories) } \\
\text { estimated that the climate change impact will decrease until } 2030 \text {, projecting a shift } \\
\text { from } 40 \text { (in 1980) to } 13 \mathrm{~g} \mathrm{CO}_{2} \text { eq/kWh by } 2030 \text {. }\end{array}$ \\
\hline Solar & - & 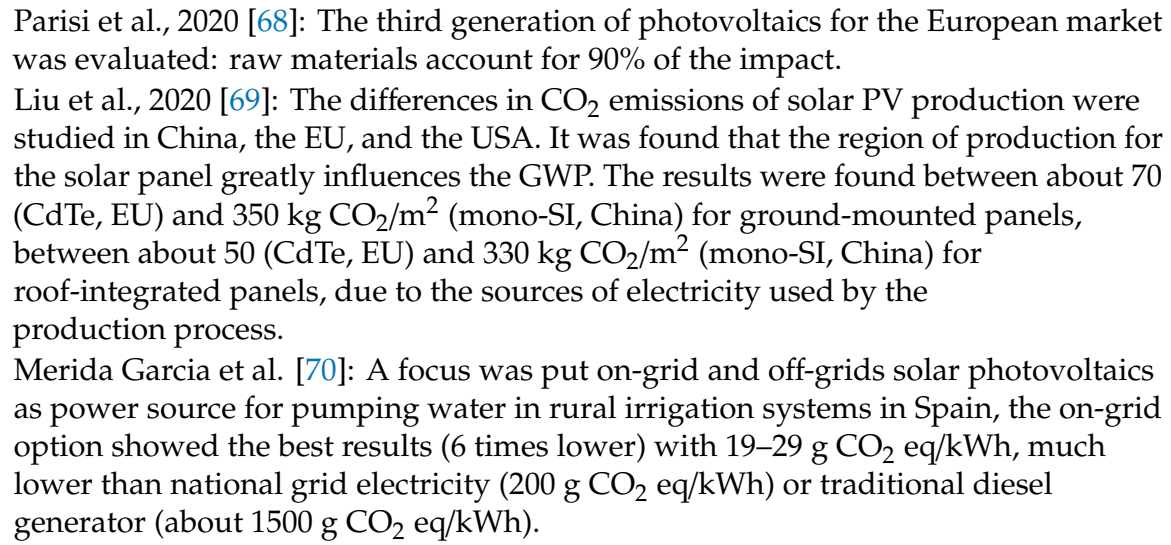 \\
\hline
\end{tabular}


Table A2. Cont.

\begin{tabular}{|c|c|c|}
\hline \multirow{5}{*}{ Biomass } & - & $\begin{array}{l}\text { Zang et al., } 2020 \text { [71]: Biomass integrated gasification combined cycle (BIGCC) } \\
\text { systems were evaluated and compared the mixed electricity grid of EU27, the results } \\
\text { were } 240 \mathrm{~kg} \mathrm{CO} 2 \text { eq/MWh (which is } 43 \% \text { lower than the intensity of the EU } 27 \\
\text { electricity mix) and even negative with CCS systems inclusion. Even though the } \\
\text { other environmental impacts were higher with than without CCS systems, these } \\
\text { impacts were lower than the current EU27 electricity mix. }\end{array}$ \\
\hline & - & $\begin{array}{l}\text { Masum et al., } 2020 \text { [72]: The carbon intensity of electricity generation from bioenergy } \\
\text { feedstocks was evaluated in Georgia, USA. Pine chips had the best performance with } \\
\text { less than } 134 \mathrm{~kg} \mathrm{CO} 2 \mathrm{e} / \mathrm{MWh} \text {, most of the impact occurred at processing stage. The } \\
\text { cost is still a disadvantage ( } 113 \$ / \mathrm{MWh} \text { vs. } 95.1 \$ / \mathrm{MWh} \text { for the coal-based electricity) } \\
\text { however if the processing cost is reduced, it could lower the total cost of biopower. }\end{array}$ \\
\hline & - & $\begin{array}{l}\text { Beagle et al., } 2019 \text { [20]: The study focused on biomass utilization for electricity } \\
\text { generation in the EU and in the USA, it was found out that for } 1 \mathrm{kWh} \text { generated, the } \\
\text { GWP could be } 76 \% \text { lower than coal-based electricity ( } 0.28 \mathrm{vs} .1 \mathrm{~kg} \mathrm{CO} 2 / \mathrm{kWh} \text { ), } \\
\text { however the results are largely dependent on the biomass heating value, the type of } \\
\text { wood (chips or pellets), and the biomass transportation distance. }\end{array}$ \\
\hline & - & $\begin{array}{l}\text { Sanchez Moore et al., } 2019 \text { [73]: A focus on co-generation process operated with } \\
\text { sugarcane biomass (bagasse and straw) in Brazil, the lowest environmental impact } \\
\text { was found at } 688 \mathrm{~kg} \mathrm{CO} \text { eq/MWh with a high boiler operating pressure (100 bar), a } \\
\text { straw addition rate of } 50 \% \text { and a low moisture content (10\%). }\end{array}$ \\
\hline & - & $\begin{array}{l}\text { Yan et al., } 2019 \text { [74]: A novel biomass fueled power plant with carbon capture and } \\
\text { sequestration (BFP-CCS) is analyzed. The life cycle emissions } \mathrm{CO}_{2} \text { was }-0.591 \mathrm{~kg} \\
\mathrm{CO}_{2} / \mathrm{kWh} \text { with a levelized cost of electricity of } 0.0501 \$ / \mathrm{kWh} \text {. }\end{array}$ \\
\hline
\end{tabular}

- $\quad$ Paulillo et al., 2020 [75]: A deep geothermal power plant in the UK was assessed: it was shown that steel and diesel consumption need for the plant construction are mainly the source of environmental impacts. The climate change impact was found slightly lower than solar power but higher than wind and nuclear power. The other impact categories show more or less the same tendency.

- $\quad$ Karlsdottir et al., 2020 [76]: Geothermal combined heat and power (CHP) plant was

Geothermal evaluated in Iceland. Again, the construction stage contributed to most of the impacts. The direct emissions of the plant affect the global warming impact $(15.9 \mathrm{~g}$ $\mathrm{CO}_{2} \mathrm{eq} / \mathrm{kWh}$ ).

- $\quad$ Paulillo et al., 2020 [77]: LCA study on a geothermal power plant in Iceland. The carbon intensity was found in the range of $15-24 \mathrm{~g} \mathrm{CO}_{2} \mathrm{eq} / \mathrm{kWh}$ depending on the configuration (Single flash or double flash). The construction made of steel and copper has an important role in the different impact categories.

- $\quad$ Yuguda et al., 2020 [78]: A retrofitting dam to generate hydro-electricity in Nigeria was evaluated. The construction stage is responsible for about $90 \%$ of all the different environmental impacts during the life-cycle. The GWP is found between 1.61 and $5.51 \mathrm{~kg} \mathrm{CO} 2 \mathrm{eq} / \mathrm{kWh}$ due to the construction composed of steel.

- $\quad$ Ueda et al., 2019 [79] focused on 11 micro-hydropower installations in the UK, it was shown that alternative materials such as wood-frame powerhouse instead of concrete construction could lead to a reduction of about $10 \%$ of the GWP. The results were found between about 4 and $15 \mathrm{~g} \mathrm{CO}_{2} \mathrm{eq} / \mathrm{kWh}$. The authors concluded that the Hydro inventories in the different case studies for renewables could significantly influence the environmental assessment.

- $\quad$ Parvez Mahmud et al., 2019 [80]: The study focused on hydropower plants comparing alpine and non-alpine regions in Europe, the global warming impact was shown 10 times higher in the latter one $(1.41 \times 10-3 \mathrm{~kg} \mathrm{CO} 2 \mathrm{eq} / \mathrm{kWh})$, it was concluded that studies should focus more on construction materials.

- $\quad$ Kaddoura et al., 2020 [81]: A prospective LCA was performed on a $12 \mathrm{MW}$ tidal energy converter array, the GWP was evaluated in the range $18.4-26.3 \mathrm{~g} \mathrm{CO}_{2} \mathrm{eq} / \mathrm{kWh}$ with operation and maintenance having a major contribution as well as the gravity based foundation (GBF) even though many parts are recycled at the end of life. 
Table A3. Life-cycle emission factors for electricity generation (adapted from [8]).

\begin{tabular}{|c|c|c|c|}
\hline Energy Source & $\mathrm{CO}_{2}$-eq $(\mathrm{kg} / \mathrm{MWh})$ & NOx (kg/MWh) & $\mathrm{SO}_{2}(\mathrm{~kg} / \mathrm{MWh})$ \\
\hline Hard coal & $660-1050$ & $0.3-3.9$ & $0.3-6.7$ \\
\hline Lignite & $800-1300$ & $0.2-1.7$ & $0.6-7$ \\
\hline Natural gas & $380-1000$ & $0.2-3.8$ & $0.01-0.32$ \\
\hline Oil & $530-900$ & $0.5-1.5$ & $0.85-8$ \\
\hline Nuclear power & $3-35$ & $0.01-0.04$ & $0.003-0.038$ \\
\hline Biomass & $8.5-130$ & $0.08-1.7$ & $0.03-0.94$ \\
\hline Hydropower & $2-20$ & $0.004-0.06$ & $0.001-0.003$ \\
\hline Solar energy & 13-190 & $0.15-0.40$ & $0.12-0.29$ \\
\hline Wind & $3-41$ & $0.02-0.11$ & $0.02-0.09$ \\
\hline
\end{tabular}

Table A4. Overview of the LIME3 method.

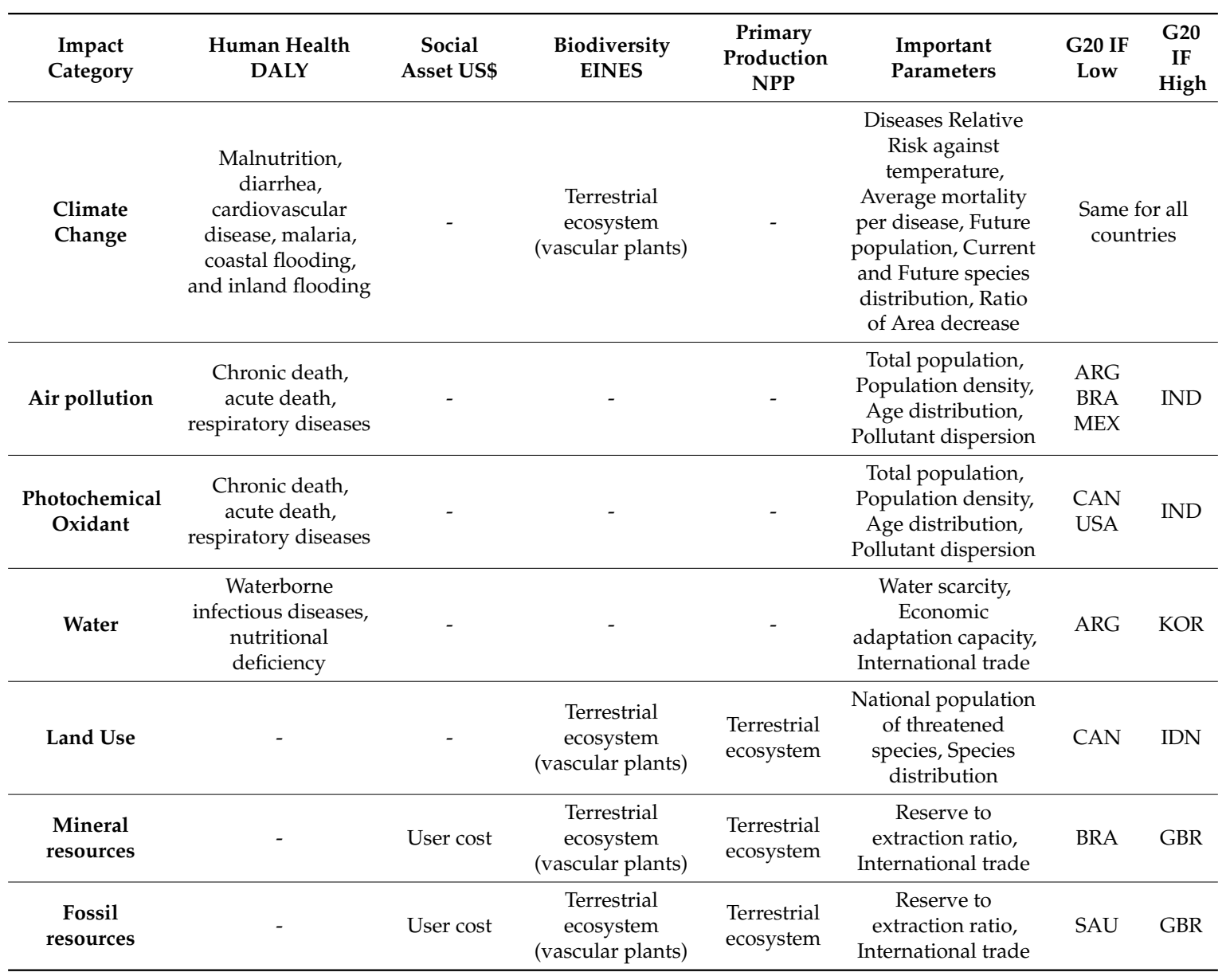


Table A5. LIME3 integration factors used in this study (Inside each category from dark green (Low integration factor) to dark red (High integration factor)).

\begin{tabular}{|c|c|c|c|c|c|c|c|c|c|c|c|c|c|c|c|c|c|c|c|}
\hline & ARG & AUS & BRA & CAN & CHN & DEU & FRA & GBR & IDN & IND & ITA & JPN & KOR & MEX & RUS & SAU & TUR & USA & ZAF \\
\hline $\mathrm{CO}_{2}(\$ / \mathrm{kg})$ & $1.71 \times 10^{-2}$ & $1.71 \times 10^{-2}$ & $1.71 \times 10^{-2}$ & $1.71 \times 10^{-2}$ & $1.71 \times 10^{-2}$ & $1.71 \times 10^{-2}$ & $1.71 \times 10^{-2}$ & $1.71 \times 10^{-2}$ & $1.71 \times 10^{-2}$ & $1.71 \times 10^{-2}$ & $1.71 \times 10^{-2}$ & $1.71 \times 10^{-2}$ & $1.71 \times 10^{-2}$ & $1.71 \times 10^{-2}$ & $1.71 \times 10^{-2}$ & $1.71 \times 10^{-2}$ & $1.71 \times 10^{-2}$ & $1.71 \times 10^{-2}$ & $1.71 \times 10^{-2}$ \\
\hline & $.18 \times 10^{-1}$ & 1.02 & $6.18 \times 10^{-1}$ & $7.87 \times 10^{-1}$ & 4.33 & 2.84 & 2.84 & 2.84 & 1.02 & 5.11 & 2.84 & 1.58 & 4.33 & $6.18 \times 10^{-1}$ & 1.85 & 2.52 & 1.85 & $7.87 \times 10^{-1}$ & 1.240 \\
\hline & -1 & & & & $4.96 \mathrm{C}$ & & & 11 & & 8.6 & & & 4.9 & & & .3 & 16 & $0^{-1}$ & \\
\hline $\begin{array}{c}\text { NMVOC } \\
(\$ / \mathbf{k g})\end{array}$ & $57 \times 10^{-3}$ & $9.41 \times 10^{-3}$ & $557 \times 10^{-3}$ & $4.63 \times 10^{-2}$ & $1.28 \times 10^{-1}$ & $8.11 \times 10^{-2}$ & $8.11 \times 10^{-2}$ & $3.11 \times 10^{-2}$ & $9.41 \times 10^{-3}$ & $6.69 \times 10^{-2}$ & $8.11 \times 10^{-2}$ & $4.25 \times 10^{-2}$ & $1.28 \times 10^{-1}$ & $5.57 \times 10^{-3}$ & $4.10 \times 10^{-2}$ & $3.15 \times 10^{-2}$ & $4.10 \times 10^{-2}$ & $4.63 \times 10^{-2}$ & $1.12 \times 10^{-2}$ \\
\hline & .80 & 4.14 & 1.80 & 3.22 & $1 \times 10^{1}$ & $2 \times 10^{1}$ & $02 \times 10^{1}$ & $02 \times 10^{1}$ & 4.14 & $64 \times 10^{1}$ & $02 \times 10^{1}$ & $20 \times$ & $2.51 \times 10^{1}$ & 1.80 & 4.21 & 9.15 & 4.21 & 3.22 & 4.05 \\
\hline & & $57 \times 10^{-1}$ & & & & & & & & & & & & & $1.68 \times 10^{-1}$ & & & & \\
\hline & $2.12 \times 10^{-3}$ & $1.35 \times 10^{-3}$ & $1.98 \times 10^{-3}$ & $3.98 \times 10^{-3}$ & $2.92 \times 10^{-2}$ & $1.04 \times 10^{-3}$ & $1.76 \times 10^{-3}$ & $392 \times 10^{-2}$ & $.84 \times 10^{-2}$ & $.03 \times 10^{-3}$ & $177 \times 10^{-2}$ & $1.30 \times 10^{-2}$ & $2.42 \times 10^{-2}$ & $1.75 \times 10^{-3}$ & $6.12 \times 10^{-4}$ & $2.12 \times 10^{-2}$ & $3.41 \times 10^{-2}$ & $1.82 \times 10^{-3}$ & $1.78 \times 10^{-3}$ \\
\hline & & & & & & & $8 \times$ & & & & $.13 \times 10^{-2}$ & $7.65 \times$ & $.61 \times 1$ & & & & & & \\
\hline & $1.60 \times 10^{-4}$ & $5.83 \times 10^{-2}$ & $2.95 \times 10^{-2}$ & $2.75 \times 10^{-2}$ & 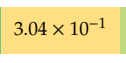 & $1.15 \times 10^{-1}$ & $9.98 \times 10^{-2}$ & $708-1$ & $.02 \times 10-^{1}$ & $5.69 \times 10^{-1}$ & $1.90 \times 10^{-1}$ & $9.34 \times 10^{-1}$ & 1.70 & $2.43 \times 10^{-1}$ & $3.68 \times 10^{-2}$ & $8.35 \times 10^{-4}$ & $2.69 \times 10^{-1}$ & $3.32 \times 10^{-1}$ & $4.01 \times 10^{-1}$ \\
\hline $\operatorname{Ag}(\$ / \mathrm{kg})$ & $\times 10^{2}$ & $2.01 \times 10^{2}$ & $6.40 \times 10^{2}$ & $8.88 \times 10^{2}$ & $1.62 \times 10^{2}$ & $5.04 \times 10^{2}$ & $5 \times 10^{2}$ & $65 \times 10^{2}$ & $6.47 \times 10^{2}$ & $5.64 \times 10^{2}$ & $6.65 \times 10^{2}$ & $1.19 \times 10^{2}$ & $5.56 \times 10^{2}$ & $9.46 \times 10^{2}$ & $5.10 \times 10^{2}$ & $5.64 \times 10^{2}$ & $5.64 \times 10^{2}$ & $5.95 \times 10^{2}$ & \\
\hline $\mathrm{Al}(\mathbf{\$} / \mathrm{kg})$ & $4 \times 10^{-1}$ & $1.02 \times 10^{-1}$ & $2.28 \times 10^{-2}$ & $2.43 \times 10^{-2}$ & 1.07 & $4.97 \times 10^{-2}$ & $\times 10^{-1}$ & 1.1 & $\times 10^{-1}$ & 3.74 & 1.44 & $2.25 \times 10^{-1}$ & $2.29 \times 10^{-1}$ & $6.37 \times 10^{-1}$ & 1.0 & 4.6 & 1.67 & $0^{-2}$ & \\
\hline & & $2.13 \times 10^{4}$ & $1.51 \times 10^{4}$ & $6.43 \times 10^{4}$ & $7.84 \times 10^{4}$ & $2.13 \times 10^{4}$ & $3.91 \times 10^{4}$ & $3.97 \times 10^{4}$ & $0 \times 10^{4}$ & & $3.91 \times 10^{4}$ & $4.11 \times 10^{4}$ & $6.32 \times 10^{4}$ & $2.79 \times 10^{4}$ & $2.95 \times 10^{4}$ & $4.37 \times 10^{4}$ & $3.95 \times 10^{4}$ & $5.31 \times 10^{4}$ & \\
\hline & $44 \times 10^{-3}$ & $2.43 \times 10^{-3}$ & $3.24 \times 10^{-3}$ & $2.42 \times 10^{-3}$ & $2.40 \times 10^{-3}$ & & $2.41 \times 10^{-3}$ & $13 \times 10^{-3}$ & $3 \times 10^{-3}$ & $2.96 \times 10^{-3}$ & $2.42 \times 10^{-3}$ & $2.42 \times 10^{-3}$ & $2.41 \times 10^{-3}$ & $2.42 \times 10^{-3}$ & $2.41 \times 10^{-3}$ & $2.43 \times 10^{-3}$ & $2.41 \times 10^{-3}$ & $2.43 \times 10^{-3}$ & $2.43 \times 10^{-3}$ \\
\hline Co $\$$ & $.01 \times 10^{1}$ & $1.05 \times 10^{-2}$ & 3.03 & $1.94 \times 10^{1}$ & 4.89 & $2.62 \times 10^{1}$ & $2.76 \times 10^{-2}$ & $1.01 \times 10^{1}$ & 6.34 & $2.20 \times 10^{-1}$ & $1.01 \times 10^{1}$ & $1.66 \times 10^{1}$ & $1.01 \times 10^{1}$ & $1.01 \times 10^{1}$ & $1.57 \times 10^{1}$ & $1.01 \times 10^{1}$ & $1.01 \times 10^{1}$ & $6.18 \times 10^{1}$ & 4.91 \\
\hline $\operatorname{Cr}(\$ / \mathrm{kg}$ & 9.93 & 9.94 & 9.95 & $1.0 \times 10^{1}$ & $1.02 \times 10^{1}$ & $01 \times 10^{1}$ & $1.0 \times 10^{1}$ & 9.96 & 9.94 & $1.39 \times 10^{1}$ & 9.97 & $1.22 \times 10^{1}$ & $10-\times 10^{1}$ & 9.97 & 5.48 & 9.4 & 9.93 & 9.93 & $9.93 \mathrm{Z}$ \\
\hline $\mathrm{Cu}(\$ / \mathrm{kg}$ & & $1.99 \times 10^{-1}$ & 4.4 & 8.26 & & & & 6.7 & & 3.20 & 3.19 & 3.8 & 3.22 & $5.85 \times 10^{-1}$ & 2.46 & 3.6 & 3.3 & & 3.9 \\
\hline Eu $(\$ / k g)$ & $30 \times 10^{-1}$ & $1.29 \times 10^{-1}$ & $1.24 \times 10^{-1}$ & $1.48 \times 10^{-1}$ & $1.23 \times 10^{-1}$ & $1.29 \times 10^{-1}$ & $1.26 \times 10^{-1}$ & $1.30 \times 10^{-1}$ & $1.30 \times 10^{-1}$ & $1.53 \times 10^{-1}$ & $1.27 \times 10^{-1}$ & $1.26 \times 10^{-1}$ & $1.25 \times 10^{-1}$ & $1.28 \times 10^{-1}$ & $1.24 \times 10^{-1}$ & $9.87 \times 10^{-2}$ & $1.25 \times 10^{-1}$ & $1.27 \times 10^{-1}$ & $1.30 \times 10^{-1}$ \\
\hline & $3 \times 10^{-3}$ & $8.87 \times 10^{-3}$ & $2.73 \times 10^{-3}$ & $7.50 \times 10^{-4}$ & $8.69 \times 10^{-2}$ & $5.71 \times 10^{-3}$ & $3.24 \times 10^{-3}$ & $1.57 \times 10^{-2}$ & $1.81 \times 10^{-3}$ & $4.74 \times 10^{-2}$ & $8.27 \times 10^{-3}$ & $1.32 \times 10^{-2}$ & $1.10 \times 10^{-2}$ & $1.10 \times 10^{-2}$ & $2.88 \times 10^{-4}$ & $5.28 \times 10^{-2}$ & $3.50 \times 10^{-3}$ & $1.15 \times 10^{-3}$ & $8.21 \times 10^{-2}$ \\
\hline & & $4.54 \times 10^{-1}$ & $4.42 \times 10^{-1}$ & $5.26 \times 10^{-1}$ & $4.41 \times 10^{-1}$ & $2 \times 10^{-1}$ & $10^{-1}$ & & $4.54 \times 10^{-1}$ & $4.55 \times 10^{-1}$ & $4.49 \times 10^{-1}$ & & $\times 10^{-1}$ & $4.50 \times 10^{-1}$ & $4.43 \times 10^{-1}$ & $\times 10^{-1}$ & $4.44 \times 10^{-1}$ & $4.49 \times 10^{-1}$ & $4.55 \times 10^{-1}$ \\
\hline La $(\mathrm{S} / \mathrm{kg})$ & $\times 10^{-2}$ & $8.96 \times 10^{-2}$ & $1.16 \times 10^{-1}$ & $8.93 \times 10^{-2}$ & $8.89 \times 10^{-2}$ & $8.95 \times 10^{-2}$ & $8.92 \times 10^{-2}$ & $8.97 \times 10^{-2}$ & $8.96 \times 10^{-2}$ & $1.08 \times 10^{-1}$ & $8.93 \times 10^{-2}$ & $8.93 \times 10^{-2}$ & $8.92 \times 10^{-2}$ & $8.94 \times 10^{-2}$ & $8.90 \times 10^{-2}$ & $8.98 \times 10^{-2}$ & $8.91 \times 10^{-2}$ & $8.97 \times 10^{-2}$ & $8.97 \times 10^{-2}$ \\
\hline Li $(\$ / k g)$ & $3.44 \times 10^{-4}$ & 1.15 & $3.80 \times 10^{-1}$ & $2.24 \times 10^{-14}$ & $1.03 \times 10^{-1}$ & $6.74 \times 10^{-1}$ & $5.16 \times 10^{-1}$ & $5.20 \times 10^{-1}$ & $6.10 \times 10^{-1}$ & $1.62 \times 10^{-1}$ & $2.43 \times 10^{-1}$ & $4.25 \times 10^{-1}$ & $6.10 \times 10^{-1}$ & $1.19 \times 10^{-2}$ & $1.50 \times 10^{-1}$ & $6.10 \times 10^{-1}$ & $6.10 \times 10^{-1}$ & $7.64 \times 10^{-1}$ & $1.32 \times 10^{-1}$ \\
\hline $\mathrm{Mn}(\mathrm{s} / \mathrm{kg})$ & $3.78 \times 10^{-2}$ & $8.86 \times 10^{-1}$ & $1.08 \times 10^{-2}$ & $6.55 \times 10^{-1}$ & 1.62 & $3.87 \times 10^{-1}$ & $1.07 \times 10^{-1}$ & $3.87 \times 10^{-1}$ & $9.43 \times 10^{-1}$ & $5.11 \times 10^{-1}$ & $4.03 \times 10^{-1}$ & $5.12 \times 10^{-1}$ & $7.07 \times 10^{-1}$ & 2.11 & $3.52 \times 10^{-1}$ & $4.93 \times 10^{-1}$ & $4.34 \times 10^{-1}$ & $5.48 \times 10^{-1}$ & $3.47 \times 10^{-1}$ \\
\hline Mo $(\$ / \mathrm{kg})$ & & & 7.04 & 8.54 & 4.45 & & 6.38 & 4.43 & & 6.38 & 5.22 & 8.75 & 5.86 & 3.88 & 3.22 & & .22 & & 7.91 \\
\hline & $1.05 \times 10^{-1}$ & $1.05 \times 10^{-1}$ & $1.37 \times 10^{-1}$ & $1.04 \times 10^{-1}$ & $1.04 \times 10^{-1}$ & $1.05 \times 10^{-1}$ & $1.04 \times 10^{-1}$ & $1.05 \times 10^{-1}$ & $1.05 \times 10^{-1}$ & 1.27 & $1.04 \times 10^{-1}$ & $1.04 \times 10-^{1}$ & $1.04 \times 10^{-1}$ & $1.05 \times 10^{-1}$ & $0^{-1}$ & $1.05 x$ & $<10^{-1}$ & $1.05 \times 10^{-1}$ & \\
\hline $\mathrm{Ni}(\mathrm{S} / \mathrm{kg})$ & $1.43 \times 10^{1}$ & $5.80 \times 10^{-2}$ & $8.67 \times 10^{-2}$ & $1.40 \times 10^{1}$ & $2.13 \times 10^{1}$ & $1.43 \times 10^{1}$ & 1.33 & $1.43 \times 10^{1}$ & $1.43 \times 10^{1}$ & $1.43 \times 10^{1}$ & $1.43 \times 10^{1}$ & $2.15 \times 10^{1}$ & 1.33 & $1.43 \times 10^{1}$ & $1.78 \times 10^{1}$ & $1.43 \times 10^{1}$ & $1.43 \times 10^{1}$ & $1.43 \times 10^{1}$ & $3.16 \times 10^{-1}$ \\
\hline $\mathrm{Pb}(\mathrm{S} / \mathrm{kg})$ & 3.09 & $7.33 \times 10^{-1}$ & 2.75 & 3.2 & 3.35 & & 2.75 & 3.0 & 2. & 1.89 & 2.7 & 1.55 & 1.46 & 1.09 & 3.0 & 2.75 & 3.09 & 2.53 & 4.34 \\
\hline $\operatorname{Pd}(\mathbf{S} / \mathbf{k g})$ & $2.66 \times 10^{4}$ & $2.66 \times 10^{4}$ & $4.46 \times 10^{3}$ & $2.47 \times 10^{4}$ & $1.23 \times 10^{4}$ & $6.90 \times 10^{3}$ & $6.07 \times 10^{3}$ & $1.87 \times 10^{4}$ & $2.66 \times 10^{4}$ & $2.66 \times 10^{4}$ & $1.63 \times 10^{4}$ & $1.48 \times 10^{4}$ & $1.24 \times 10^{4}$ & $2.66 \times 10^{4}$ & $2.66 \times 10^{4}$ & $2.66 \times 10^{4}$ & $2.66 \times 10^{4}$ & $1.42 \times 10^{4}$ & $2.66 \times 10^{4}$ \\
\hline $\operatorname{Pr}(\$ / \mathrm{kg})$ & $3.00 \times 10^{-1}$ & $2.98 \times 10^{-1}$ & $3.89 \times 10^{-1}$ & $2.97 \times 10^{-1}$ & $2.95 \times 10^{-1}$ & $2.97 \times 10^{-1}$ & $2.96 \times 10^{-1}$ & $2.98 \times 10^{-1}$ & $2.98 \times 10^{-1}$ & $3.60 \times 10^{-1}$ & $2.97 \times 10^{-1}$ & $2.97 \times 10^{-1}$ & $2.96 \times 10^{-1}$ & $2.97 \times 10^{-1}$ & $2.96 \times 10^{-1}$ & $2.98 \times 10^{-1}$ & $2.96 \times 10^{-1}$ & $2.98 \times 10^{-1}$ & $2.98 \times 10^{-1}$ \\
\hline Pt $(\$ / k g)$ & & $3.88 \times 10^{4}$ & $2.25 \times 10^{3}$ & $2.37 \times 10^{4}$ & $2.37 \times 10^{3}$ & $1.21 \times 10^{4}$ & $3.46 \times 10^{3}$ & $5.62 \times 10^{4}$ & & $2.88 \times 10^{4}$ & $1.88 \times 10^{4}$ & $1.52 \times 10^{4}$ & $\times 10^{4}$ & $2.88 \times 10^{4}$ & $1.19 \times 10^{5}$ & $\times 10^{4}$ & $\times 10^{4}$ & $2 \times 10^{3}$ & $2.88 \times 10^{4}$ \\
\hline & & & $\times 10^{2}$ & $2.42 \times 10^{3}$ & $8.14 \times 10^{2}$ & & $\times 10^{2}$ & & & $8.14 \times 10^{2}$ & $\times 10^{2}$ & & & $8.14 \times 10^{2}$ & $3.75 \times 10^{-1}$ & & & $10^{2}$ & $8.14 \times 10^{2}$ \\
\hline & & & 6.13 & 1.25 & $2.44 \times 10^{1}$ & & & $2.01 \times 10^{1}$ & 2.3 & 1.25 & $2.01 \times 10^{1}$ & $\times 10^{1}$ & $1 \times 10^{1}$ & 1.25 & $4.08 \times 1 c$ & $2.01 \times 10^{1}$ & $2.01 \times 10^{1}$ & $\times 10^{1}$ & 1.25 \\
\hline $\operatorname{Sr}(\mathbf{S} / \mathbf{k g})$ & $3.96 \times 10^{-1}$ & $4.48 \times 10^{-1}$ & $4.48 \times 10^{-1}$ & $4.48 \times 10^{-1}$ & $4.24 \times 10^{-1}$ & $6.00 \times 10^{-1}$ & $4.69 \times 10^{-1}$ & $4.79 \times 10^{-1}$ & $4.48 \times 10^{-1}$ & $4.48 \times 10^{-1}$ & $4.86 \times 10^{-1}$ & $5.49 \times 10^{-1}$ & $5.58 \times 10^{-1}$ & $6.53 \times 10^{-1}$ & $4.48 \times 10^{-1}$ & $4.48 \times 10^{-1}$ & $4.48 \times 10^{-1}$ & $6.28 \times 10^{-1}$ & $4.48 \times 10^{-1}$ \\
\hline Ta $(\$ / \mathbf{k g})$ & $1.07 \times 10^{1}$ & $1.80 \times 10^{-1}$ & $4.30 \times 10^{-1}$ & $1.62 \times 10^{-1}$ & $7.68 \times 10^{-1}$ & $1.07 \times 10^{1}$ & $3.49 \times 10^{-1}$ & $2.26 \times 10^{-1}$ & $3.49 \times 10^{-1}$ & $3.49 \times 10^{-1}$ & $3.49 \times 10^{-1}$ & $1.80 \times 10^{-1}$ & $3.49 \times 10^{-1}$ & $3.49 \times 10^{-1}$ & $3.49 \times 10^{-1}$ & $1.07 \times 10^{1}$ & $1.07 \times 10^{1}$ & 9.06 & $1.56 \times 10^{1}$ \\
\hline $\mathrm{U}(\$ / \mathrm{kg})$ & $4.46 \times 10^{1}$ & $1.94 \times 10^{-1}$ & $1.57 \times 10^{-1}$ & $3.02 \times 10^{1}$ & $2.18 \times 10^{1}$ & $1.27 \times 10^{1}$ & $2.35 \times 10^{1}$ & $2.80 \times 10^{1}$ & $2.82 \times 10^{1}$ & 2.61 & 3.57 & $3.05 \times 10^{1}$ & $3.05 \times 10^{1}$ & $2.80 \times 10^{1}$ & $7.50 \times 10^{-1}$ & $2.80 \times 10^{1}$ & $2.80 \times 10^{1}$ & 0.80 & $56 \times 10^{-2}$ \\
\hline & 2.29 & & & & 2.97 & & 1.50 & & & & & & & & & & & & \\
\hline $\mathrm{Zr}(\$ / \mathrm{kg})$ & $1.19 \times 10^{-1}$ & $8.73 \times 10^{-2}$ & $5.13 \times 10^{-1}$ & $1.19 \times 10^{-1}$ & $1.61 \times 10^{-1}$ & $6.84 \times 10^{-2}$ & $5.35 \times 10^{-2}$ & $6.21 \times 10^{-2}$ & $4.39 \times 10^{-1}$ & $1.31 \times 10^{-1}$ & $7.53 \times 10^{-2}$ & $8.68 \times 10^{-2}$ & $9.75 \times 10^{-2}$ & $1.19 \times 10^{-1}$ & $1.53 \times 10^{-1}$ & $1.19 \times 10^{-1}$ & $1.19 \times 10^{-1}$ & $7.43 \times 10^{-2}$ & $84 \times 10^{-2}$ \\
\hline
\end{tabular}


Table A6. Inventory items having an influence on the external cost for each system.

\begin{tabular}{|c|c|c|c|c|c|c|c|c|c|c|c|c|}
\hline & HC & Lignite & NG C/CC & Oil & $\begin{array}{l}\text { Wind } \\
\text { ON/OFF }\end{array}$ & GEO & $\begin{array}{c}\text { Hydro } \\
\text { RR }\end{array}$ & Hydro PS & Hydro R & $\begin{array}{l}\text { Nuclear } \\
\text { BW/PW }\end{array}$ & Solar OG & $\begin{array}{l}\text { Solar } \\
\text { Roof }\end{array}$ \\
\hline AUS & $\begin{array}{l}1-\mathrm{CO}_{2} \\
2-\mathrm{SO}_{2}\end{array}$ & $\begin{array}{l}1-\mathrm{CO}_{2} \\
2-\mathrm{SO}_{2}\end{array}$ & $\begin{array}{l}1-\mathrm{CO}_{2} \\
2-\mathrm{SO}_{2}\end{array}$ & $\begin{array}{c}\text { 1-Oil_R } \\
2-\mathrm{CO}_{2} \\
3-\mathrm{SO}_{2}\end{array}$ & Mineral & - & Various & $\begin{array}{l}1-\mathrm{CO}_{2} \\
2-\mathrm{SO}_{2}\end{array}$ & - & - & $\begin{array}{l}\text { 1-LandO } \\
\text { 2-Mineral }\end{array}$ & $\begin{array}{c}\text { 1-Mineral } \\
\text { 2-Oil_R }\end{array}$ \\
\hline BRA & $\begin{array}{l}1-\mathrm{CO}_{2} \\
2-\mathrm{SO}_{2}\end{array}$ & $\begin{array}{c}1-\mathrm{CO}_{2} \\
2-\mathrm{PM}_{2} .5 \\
3-\mathrm{SO}_{2}\end{array}$ & $\begin{array}{c}1-\mathrm{CO}_{2} \\
\text { 2-NG_R }\end{array}$ & $\begin{array}{c}\text { 1-Oil_R } \\
2-\mathrm{CO}_{2} \\
3-\mathrm{SO}_{2}\end{array}$ & Mineral & - & - & & $\begin{array}{l}\text { 1-Water } \\
\text { 2-LandT }\end{array}$ & Mineral & $\begin{array}{l}\text { 1-LandO } \\
\text { 2-Mineral }\end{array}$ & $\begin{array}{c}\text { 1-Mineral } \\
\text { 2-CO } \\
\text { 3-Oil_R }\end{array}$ \\
\hline CAN & $\begin{array}{l}1-\mathrm{CO}_{2} \\
2-\mathrm{SO}_{2}\end{array}$ & $\begin{array}{c}1-\mathrm{CO}_{2} \\
\text { 2-PM2.5 }\end{array}$ & $\begin{array}{c}1-\mathrm{CO}_{2} \\
\text { 2-NG_R }\end{array}$ & $\begin{array}{c}\text { 1-Oil_R } \\
2-\mathrm{CO}_{2}\end{array}$ & Mineral & Various & Various & $\begin{array}{c}\text { 1-CO } \mathrm{CO}_{2} \\
\text { 2-Oil_R }\end{array}$ & $\begin{array}{c}\text { 1-Water } \\
\text { 2-Mineral }\end{array}$ & Mineral & $\begin{array}{l}\text { 1-Mineral } \\
\text { 2-LandO }\end{array}$ & Mineral \\
\hline CHN & $\begin{array}{c}1-\mathrm{SO}_{2} \\
2-\mathrm{CO}_{2} \\
3-\mathrm{PM} 2.5\end{array}$ & - & $\begin{array}{c}1-\mathrm{CO}_{2} \\
\text { 2-NG_R }\end{array}$ & $\begin{array}{c}\text { 1-Oil_R } \\
\text { 2-SO } \\
\text { 3-NOx }\end{array}$ & Mineral & $\begin{array}{c}\text { 1-PM2.5 } \\
\text { 2-Mineral }\end{array}$ & Various & $\begin{array}{c}1-\mathrm{SO}_{2} \\
2-\mathrm{CO}_{2} \\
3-\mathrm{PM} 2.5\end{array}$ & - & Mineral & $\begin{array}{l}\text { 1-Mineral } \\
\text { 2-PM2.5 }\end{array}$ & $\begin{array}{c}\text { 1-Mineral } \\
\text { 2-PM2.5 }\end{array}$ \\
\hline DEU & $\begin{array}{l}1-\mathrm{CO}_{2} \\
2-\mathrm{SO}_{2} \\
3-\mathrm{NOx} \\
\end{array}$ & $\begin{array}{l}1-\mathrm{CO}_{2} \\
\text { 2-SO } \\
\text { 3-NOx }\end{array}$ & $\begin{array}{c}1-\mathrm{CO}_{2} \\
\text { 2-NG_R }\end{array}$ & $\begin{array}{c}\text { 1-Oil_R } \\
2-\mathrm{CO}_{2} \\
3-\mathrm{SO}_{2}\end{array}$ & Mineral & $\begin{array}{c}\text { 1-Mineral } \\
\text { 2- } \mathrm{CO}_{2} \\
\text { 3-PM2.5 }\end{array}$ & Mineral & $\begin{array}{c}\text { 1- } \mathrm{CO}_{2} \\
\text { 2-SO } \\
\text { 3-Mineral }\end{array}$ & Water & Mineral & $\begin{array}{c}\text { 1-Mineral } \\
\text { 2-LandO } \\
3-\mathrm{CO}_{2}\end{array}$ & $\begin{array}{c}\text { 1-Mineral } \\
2-\mathrm{CO}_{2} \\
3-\mathrm{SO}_{2}\end{array}$ \\
\hline FRA & $\begin{array}{c}1-\mathrm{CO}_{2} \\
\text { 2-SO } \\
\text { 3-NOx }\end{array}$ & - & $\begin{array}{l}1-\mathrm{CO}_{2} \\
\text { 2-NOx }\end{array}$ & $\begin{array}{c}\text { 1-Oil_R } \\
2-\mathrm{SO}_{2} \\
3-\mathrm{CO}_{2}\end{array}$ & Mineral & $\begin{array}{c}\text { 1-CO } \\
\text { 2-PM2.5 } \\
\text { 3-Mineral }\end{array}$ & Various & $\begin{array}{c}\text { 1-Mineral } \\
2-\mathrm{CO}_{2}\end{array}$ & Water & Mineral & $\begin{array}{c}\text { 1-Mineral } \\
\text { 2-LandO } \\
\text { 3- } \mathrm{CO}_{2}\end{array}$ & $\begin{array}{c}\text { 1-Mineral } \\
2-\mathrm{CO}_{2} \\
3-\mathrm{SO}_{2}\end{array}$ \\
\hline GBR & $\begin{array}{c}\text { 1-Coal_R } \\
\text { 2- } \mathrm{SO}_{2} \\
3-\mathrm{CO}_{2}\end{array}$ & - & $\begin{array}{c}1-\mathrm{CO}_{2} \\
\text { 2-NG_R }\end{array}$ & $\begin{array}{c}\text { 1-Oil_R } \\
2-\mathrm{SO}_{2} \\
3-\mathrm{CO}_{2}\end{array}$ & Mineral & $\begin{array}{l}\text { 1-Mineral } \\
\text { 2- } \mathrm{CO}_{2}\end{array}$ & Various & $\begin{array}{c}\text { 1-Coal_R } \\
\text { 2-CO } \\
3-\mathrm{SO}_{2}\end{array}$ & - & $\begin{array}{c}\text { 1-Water } \\
\text { 2-Mineral }\end{array}$ & Mineral & Mineral \\
\hline IDN & - & $\begin{array}{c}\text { 1-PM2.5 } \\
2-\mathrm{CO}_{2}\end{array}$ & $\mathrm{CO}_{2}$ & $\begin{array}{c}\text { 1-Oil_R } \\
2-\mathrm{SO}_{2} \\
3-\mathrm{CO}_{2}\end{array}$ & Mineral & $\begin{array}{c}\text { 1-Coal_R } \\
\text { 2-Mineral } \\
\text { 3- } \mathrm{CO}_{2}\end{array}$ & - & - & $\begin{array}{l}\text { 1-Land T } \\
\text { 2-Mineral }\end{array}$ & - & - & Mineral \\
\hline IND & $\begin{array}{c}\text { 1-PM2.5 } \\
\text { 2-NOx } \\
\text { 3- } \mathrm{CO}_{2}\end{array}$ & $\begin{array}{c}\text { 1-PM2.5 } \\
\text { 2-NOx } \\
3-\mathrm{CO}_{2}\end{array}$ & $\mathrm{CO}_{2}$ & $\begin{array}{l}1-\mathrm{NOx} \\
2-\mathrm{SO}_{2}\end{array}$ & Mineral & Various & - & $\begin{array}{c}\text { 1-PM2.5 } \\
\text { 2-NOx } \\
3-\mathrm{CO}_{2}\end{array}$ & - & Various & - & $\begin{array}{c}\text { 1-Mineral } \\
\text { 2-PM2.5 }\end{array}$ \\
\hline ITA & $\begin{array}{l}1-\mathrm{CO}_{2} \\
2-\mathrm{SO}_{2} \\
3-\mathrm{NOx}\end{array}$ & - & $\begin{array}{l}1-\mathrm{CO} 2 \\
2-\mathrm{NOx}\end{array}$ & $\begin{array}{c}\text { 1-Oil_R } \\
\text { 2-SO } \\
\text { 3- } \mathrm{CO}_{2}\end{array}$ & Mineral & $\begin{array}{c}1-\mathrm{CO}_{2} \\
\text { 2-PM2.5 } \\
\text { 3-Mineral }\end{array}$ & Various & $\begin{array}{l}\text { 1-Mineral } \\
\text { 2- } \mathrm{CO}_{2}\end{array}$ & Water & Mineral & $\begin{array}{l}\text { 1-Mineral } \\
\text { 2-LandO } \\
3-\mathrm{CO}_{2}\end{array}$ & $\begin{array}{c}\text { 1-Mineral } \\
2-\mathrm{CO}_{2} \\
3-\mathrm{SO}_{2}\end{array}$ \\
\hline
\end{tabular}


Table A6. Cont.

\begin{tabular}{|c|c|c|c|c|c|c|c|c|c|c|c|c|}
\hline & $\mathrm{HC}$ & Lignite & NG $\mathrm{C} / \mathrm{CC}$ & Oil & $\begin{array}{c}\text { Wind } \\
\text { ON/OFF }\end{array}$ & GEO & $\begin{array}{c}\text { Hydro } \\
\text { RR }\end{array}$ & Hydro PS & Hydro R & $\begin{array}{l}\text { Nuclear } \\
\text { BW/PW }\end{array}$ & Solar OG & $\begin{array}{l}\text { Solar } \\
\text { Roof }\end{array}$ \\
\hline JPN & $\begin{array}{l}1-\mathrm{CO}_{2} \\
2-\mathrm{SO}_{2} \\
3-\mathrm{NOx}\end{array}$ & $\begin{array}{c}1-\mathrm{PM}^{2.5} \\
2-\mathrm{CO}_{2} \\
3-\mathrm{SO}_{2}\end{array}$ & $\mathrm{CO}_{2}$ & $\begin{array}{c}1-\mathrm{CO}_{2} \\
\text { 2-SO } \\
\text { 3-Oil_R }\end{array}$ & Mineral & $\begin{array}{c}\text { 1-Mineral } \\
\text { 2-CO } \\
\text { 3-PM2.5 }\end{array}$ & Various & $\begin{array}{c}1-\mathrm{CO}_{2} \\
2-\mathrm{SO}_{2} \\
\text { 3-Coal_R }\end{array}$ & Water & $\begin{array}{l}\text { Water } \\
\text { Mineral }\end{array}$ & - & $\begin{array}{l}\text { 1-Mineral } \\
\text { 2-Water }\end{array}$ \\
\hline KOR & $\begin{array}{l}1-\mathrm{CO}_{2} \\
2-\mathrm{NOx} \\
3-\mathrm{CO}_{2}\end{array}$ & $\begin{array}{c}1-\mathrm{PM}_{2} .5 \\
2-\mathrm{SO}_{2} \\
3-\mathrm{CO}_{2}\end{array}$ & $\mathrm{CO}_{2}$ & $\begin{array}{c}1-\mathrm{SO}_{2} \\
2-\mathrm{NOx} \\
3-\mathrm{SO}_{2}\end{array}$ & Mineral & - & Various & $\begin{array}{c}\text { 1-PM2.5 } \\
\text { 2-CO } \\
\text { 3-NOx }\end{array}$ & Water & Water & $\begin{array}{c}\text { Water } \\
\text { Mineral }\end{array}$ & $\begin{array}{c}\text { Mineral } \\
\text { Water }\end{array}$ \\
\hline MEX & $\mathrm{CO}_{2}$ & $\begin{array}{c}1-\mathrm{CO}_{2} \\
\text { 2-PM2.5 }\end{array}$ & $\begin{array}{c}\text { 1-CO2 } \\
\text { 2-NG_R }\end{array}$ & $\begin{array}{c}\text { 1-Oil_R } \\
\text { 2-CO } \\
\end{array}$ & Mineral & - & Various & - & - & Mineral & Mineral & Mineral \\
\hline RUS & $\begin{array}{l}1-\mathrm{CO}_{2} \\
2-\mathrm{SO}_{2}\end{array}$ & $\begin{array}{c}1-\mathrm{PM}_{2.5} \\
2-\mathrm{CO}_{2} \\
3-\mathrm{SO}_{2}\end{array}$ & $\mathrm{CO}_{2}$ & $\begin{array}{c}1-\mathrm{Oil} \\
2-\mathrm{CO}_{2} \\
3-\mathrm{SO}_{2}\end{array}$ & Mineral & Various & Various & $\begin{array}{c}1-\mathrm{CO}_{2} \\
2-\mathrm{PM}_{2} .5 \\
3-\mathrm{SO}_{2}\end{array}$ & Various & Mineral & - & Mineral \\
\hline SAU & - & - & $\mathrm{CO}_{2}$ & $\begin{array}{l}1-\mathrm{CO}_{2} \\
2-\mathrm{SO}_{2} \\
3-\mathrm{NOx} \\
\end{array}$ & - & - & - & - & - & - & - & Mineral \\
\hline TUR & $\begin{array}{c}\text { 1-Coal_R } \\
2-\mathrm{CO}_{2}\end{array}$ & $\begin{array}{c}1-\mathrm{PM} 2.5 \\
2-\mathrm{CO}_{2} \\
3-\mathrm{SO}_{2}\end{array}$ & $\mathrm{CO}_{2}$ & $\begin{array}{c}\text { 1-Oil_R } \\
2-\mathrm{SO}_{2} \\
3-\mathrm{CO}_{2}\end{array}$ & Mineral & Various & Various & - & Water & - & - & Mineral \\
\hline USA & $\mathrm{CO}_{2}$ & $\begin{array}{c}\text { 1-PM2.5 } \\
\text { 2- } \mathrm{CO}_{2} \\
\end{array}$ & $\begin{array}{c}1-\mathrm{CO}_{2} \\
\text { 2-NG_R }\end{array}$ & $\begin{array}{c}\text { 1-Oil_R } \\
2-\mathrm{CO}_{2} \\
\end{array}$ & Mineral & Various & Various & $\begin{array}{c}1-\mathrm{CO}_{2} \\
\text { 2-PM2.5 }\end{array}$ & Water & Mineral & Mineral & Mineral \\
\hline ZAF & $\begin{array}{l}1-\mathrm{CO}_{2} \\
2-\mathrm{SO}_{2}\end{array}$ & - & $\mathrm{CO} 2$ & $\begin{array}{c}1-\mathrm{CO}_{2} \\
2-\mathrm{Oil} \\
3-\mathrm{SO}_{2}\end{array}$ & Mineral & $\begin{array}{c}\text { 1-Mineral } \\
\text { 2- } \mathrm{CO}_{2}\end{array}$ & Various & $\begin{array}{l}1-\mathrm{CO}_{2} \\
2-\mathrm{SO}_{2}\end{array}$ & Water & Mineral & - & Mineral \\
\hline
\end{tabular}


Table A7. Electricity generation in 2018 for G20 countries (in TWh).

\begin{tabular}{cc}
\hline Argentina & 148 \\
\hline Australia & 259 \\
\hline Brazil & 596 \\
\hline Canada & 663 \\
\hline China & 7092 \\
\hline France & 571 \\
\hline Germany & 647 \\
\hline India & 1643 \\
\hline Indonesia & 268 \\
\hline Italy & 291 \\
\hline Japan & 1102 \\
\hline Mexico & 320 \\
\hline Russia & 1128 \\
\hline Saudi Arabia & 351 \\
\hline South Africa & 256 \\
\hline South Korea & 593 \\
\hline Turkey & 303 \\
\hline UK & 334 \\
\hline USA & 4429 \\
\hline
\end{tabular}

\section{References}

1. BP (British Petroleum). Available online: https://www.bp.com/content/dam/bp/business-sites/en/ global/corporate/pdfs/energy-economics/statistical-review/bp-stats-review-2019-full-report.pdf (accessed on 7 November 2019).

2. International Energy Agency (IEA). World Energy Balance 2019; IEA Publications: Paris, France, 2019.

3. IEA (International Energy Agency). Available online: https://www.iea.org/statistics/co2emissions/ (accessed on 8 October 2019).

4. Crippa, M.; Guizzardi, D.; Muntean, M.; Schaaf, E.; Dentener, F.; van Aardenne, J.A.; Monni, S.; Doering, U.; Olivier, J.G.J.; Pagliari, V.; et al. Gridded Emissions of Air Pollutants for the period 1970-2012 within EDGAR v4.3.2. Earth Syst. Sci. Data 2018, 10, 1987-2013. [CrossRef]

5. Enerdata. Available online: https://yearbook.enerdata.net/coal-lignite/coal-world-consumption-data.html (accessed on 8 October 2019).

6. IEA (International Energy Agency). Available online: https://www.iea.org/gas2018/ (accessed on 14 May 2019).

7. IEA (International Energy Agency). Available online: https://www.iea.org/geco/oil/ (accessed on 14 May 2019).

8. Turconi, R.; Boldrin, A.; Astrup, T. Life cycle assessment (LCA) of electricity generation technologies: Overview, comparability and limitations. Renew. Sustain. Energy Rev. 2013, 28, 555-565. [CrossRef]

9. Cuéllar-Franca, R.M.; Azapagic, A. Carbon capture, storage and utilisation technologies: A critical analysis and comparison of their life cycle environmental impacts. J. $\mathrm{CO}_{2}$ Util. 2015, 9, 82-102. [CrossRef]

10. EASAC. Available online: https://easac.eu/fileadmin/PDF_s/reports_statements/Negative_Carbon/EASAC_ Report_on_Negative_Emission_Technologies.pdf (accessed on 25 February 2019).

11. Sher, F.; Iqbal, S.Z.; Liu, H.; Imran, M.; Snape, C.E. Thermal and kinetic analysis of diverse biomass fuels under different reaction environment: A way forward to renewable energy sources. Energy Convers. Manag. 2020, 203, 112266. [CrossRef]

12. Sher, F.; Kawai, A.; Güleç, F.; Sadiq, H. Sustainable energy saving alternatives in small buildings. Sustain. Energy Technol. Assess. 2019, 32, 92-99. [CrossRef] 
13. Santoyo-Castelazo, E.; Azapagic, A. Sustainability assessment of energy systems: Integrating environmental, economic and social aspects. J. Clean. Prod. 2014, 80, 119-138. [CrossRef]

14. Zhu, Y.; Jiang, S.; Zhao, Y.; Li, H.; He, G.; Li, L. Life-cycle-based water footprint assessment of coal-fired power generation in China. J. Clean. Prod. 2020, 254, 120098. [CrossRef]

15. Restrepo, Á.; Bazzo, E.; Miyake, R. A life cycle assessment of the Brazilian coal used for electric power generation. J. Clean. Prod. 2015, 92, 179-186. [CrossRef]

16. Aguirre-Villegas, H.A.; Benson, C.H. Case history of environmental impacts of an Indonesian coal supply chain. J. Clean. Prod. 2017, 157, 47-56. [CrossRef]

17. Vieira, M.D.M.; Huijbregts, M.A.J. Comparing mineral and fossil surplus costs of renewable and non-renewable electricity production. Int. J. Life Cycle Assess. 2018, 23, 840-850. [CrossRef]

18. Rimos, S.; Hoadley, A.F.; Brennan, D.J. Resource depletion impact assessment: Impacts of a natural gas scarcity in Australia. Sustain. Prod. Consum. 2015, 3, 45-58. [CrossRef]

19. Chary, K.; Aubin, J.; Guindé, L.; Sierra, J.; Blazy, J. Cultivating biomass locally or importing it? LCA of biomass provision scenarios for cleaner electricity production in a small tropical island. Biomass Bioenergy 2018, 110, 1-12. [CrossRef]

20. Beagle, E.; Belmont, E. Comparative life cycle assessment of biomass utilization for electricity generation in the European Union and the United States. Energy Policy 2019, 128, 267-275. [CrossRef]

21. U.S Energy Information Administration. Available online: https://www.eia.gov/energyexplained/index.php? page=nuclear_environment (accessed on 7 November 2019).

22. Serp, J.; Poinssot, C.; Bourg, S. Assessment of the Anticipated Environmental Footprint of Future Nuclear Energy Systems. Evidence of the Beneficial Effect of Extensive Recycling. Energies 2017, 10, 1445. [CrossRef]

23. Frischknecht, R.; Braunschweig, A.; Hofstetter, P.; Suter, P. Human health damages due to ionising radiation in life cycle impact assessment. Environ. Impact Assess. Rev. 2000, 20, 159-189. [CrossRef]

24. Jin, Y.; Behrens, P.; Tukker, A.; Scherer, L. Water use of electricity technologies: A global meta-analysis. Renew. Sustain. Energy Rev. 2019, 115, 109391. [CrossRef]

25. Lieberei, J.; Gheewala, S.H. Resource depletion assessment of renewable electricity generation technologies-Comparison of life cycle impact assessment methods with focus on mineral resources. Int. Life Cycle Assess. 2017, 22, 185-198. [CrossRef]

26. Dorber, M.; Mattson, K.R.; Sandlund, O.T.; May, R.; Verones, F. Quantifying net water consumption of Norwegian hydropower reservoirs and related aquatic biodiversity impacts in Life Cycle Assessment. Environ. Impact Assess. Rev. 2019, 76, 36-46. [CrossRef]

27. Laurent, A.; Espinosa, N.; Hauschild, M. Life Cycle Assessment Theory and Practice; Chapter 26; Springer: Berlin/Heidelberg, Germany, 2018.

28. European Environment Agency. Available online: https://www.eea.europa.eu/data-and-maps/indicators/ en35-external-costs-of-electricity-production-1\#tab-figures-supporting-this (accessed on 10 June 2019).

29. Rafaj, P.; Kypreos, S. Internalisation of external cost in the power generation sector: Analysis with Global Multi-regional MARKAL model. Energy Policy 2007, 35, 828-843. [CrossRef]

30. Streimikiene, D.; Alisauskaite-Seskiene, I. External costs of electricity generation options in Lithuania. Renew. Energy 2014, 64, 215-224. [CrossRef]

31. Vrhovcak, M.B.; Tomsic, Z.; Debrecin, N. External costs of electricity production: Case study Croatia. Energy Policy 2005, 33, 1385-1395. [CrossRef]

32. Dimitrijevic, Z.; Tatic, K.; Knezevic, A.; Salihbegovic, I. External costs from coal-fired thermal plants and sulphur dioxide emission limit values for new plants in Bosnia and Herzegovina. Energy Policy 2011, 39, 3036-3041. [CrossRef]

33. Czarnowska, L.; Frangopoulos, C.A. Dispersion of pollutants, environmental externalities due to a pulverized coal power plant and their effect on the cost of electricity. Energy 2012, 41, 212-219. [CrossRef]

34. Klaasen, G.; Riahi, K. Internalizing externalities of electricity generation: An analysis with MESSAGE-MACRO. Energy Policy 2007, 35, 815-827. [CrossRef]

35. Mahapatra, D.; Shukla, P.; Dhar, S. External cost of coal based electricity generation: A tale of Ahmedabad city. Energy Policy 2012, 49, 253-265. [CrossRef]

36. Wang, C.; Zhang, L.; Zhou, P.; Chang, Y.; Zhou, D.; Pang, M.; Yin, H. Assessing the environmental externalities for biomass- and coal-fired electricity generation in China: A supply chain perspective. J. Environ. Manag. 2019, 246, 758-767. [CrossRef] 
37. Istrate, I.; García-Gusano, D.; Iribarren, D.; Dufour, J. Long-term opportunities for electricity production through municipal solid waste incineration when internalising external costs. J. Clean. Prod. 2019, 215, 870-877. [CrossRef]

38. Cel, W.; Czechowska-Kosacka, A.; Kujawska, J.; Wasag, H. External costs as a measure of environmental impact in the generation of electricity in Poland. IOP Conf. Ser. Earth Environ. Sci. 2018, 150, 012028. [CrossRef]

39. Karimzadegan, H.; Rahmatian, M.; Farsiabi, M.M.; Meiboudi, H. Social cost of fossil-based electricity generation plants in Iran. Environ. Eng. Manag. J. 2015, 14, 2373-2382.

40. Buke, T.; Kone, A.C. Estimation of the health benefits of controlling air pollution from the Yatagan coal-fired power plant. Environ. Sci. Policy 2011, 14, 1113-1120. [CrossRef]

41. Georgakellos, D.A. Impact of a possible environmental externalities internalisation on energy prices: The case of the greenhouse gases from the Greek electricity sector. Energy Econ. 2010, 32, 202-209. [CrossRef]

42. Turtos Carbonell, L.; Meneses Ruiz, E.; Sanchez Gacita, M.; Rivero Oliva, J.; Díaz Rivero, N. Assessment of the impacts on health due to the emissions of Cuban power plants that use fossil fuel oils with high content of sulfur. Estim. Extern. Costs Atmos. Environ. 2007, 41, 2202-2213. [CrossRef]

43. Spalding-Fecher, R.; Matibe, D.K. Electricity and externalities in South Africa. Energy Policy 2003, 31, 721-734. [CrossRef]

44. Inaba, A.; Itsubo, N. Preface. Int. J. Life Cycle Assess. 2018, 23, 2271-2275. [CrossRef]

45. Itsubo, N.; Murakami, K.; Kuriyama, K.; Yoshida, K.; Tokimatsu, K.; Inaba, A. Development of weighting factors for G20 countries-Explore the difference in environmental awareness between developed and emerging countries. Int. J. Life Cycle Assess. 2018, 23, 2311-2326. [CrossRef]

46. Murakami, K.; Itsubo, N.; Kuriyama, K.; Yoshida, K.; Tokimatsu, K. Development of weighting factors for G20 countries. Part 2: Estimation of willingness to pay and annual global damage cost. Int. J. Life Cycle Assess. 2018, 23, 2349-2364. [CrossRef]

47. Huijbregts, M.A.J.; Steinmann, Z.J.N.; Elshout, P.M.F.; Stam, G.; Verones, F.; Vieira, M.; Zijp, M.; Hollander, A.; Van Zelm, R. ReCiPe2016: A harmonised life cycle impact assessment method at midpoint and endpoint level. Int. J. Life Cycle Assess. 2017, 22, 138-147. [CrossRef]

48. Bulle, C.; Margni, M.; Patouillard, L.; Boulay, A.M.; Bourgault, G.; De Bruille, V.; Cao, V.; Hauschild, M.; Henderson, A.; Humbert, S.; et al. IMPACT World+: A globally regionalized life cycle impact assessment method. Int. J. Life Cycle Assess. 2019, 24, 1653-1674. [CrossRef]

49. Tang, L.; Ii, R.; Tokimatsu, K.; Itsubo, N. Development of human health damage factors related to $\mathrm{CO}_{2}$ emissions by considering future socioeconomic scenarios. Int. J. Life Cycle Assess. 2018, 23, 2288-2299. [CrossRef]

50. Tang, L.; Higa, M.; Tanaka, N.; Itsubo, N. Assessment of global warming impact on biodiversity using the extinction risk index in LCIA: A case study of Japanese plant species. Int. J. Life Cycle Assess. 2018, 23, 314-323. [CrossRef]

51. Tang, L.; Nagashima, T.; Hasegawa, K.; Ohara, T.; Sudo, K.; Itsubo, N. Development of human health damage factors for PM2.5 based on a global chemical transport model. Int. J. Life Cycle Assess. 2018, 23, 2300-2310. [CrossRef]

52. Tang, L.; Nagashima, T.; Hasegawa, K.; Ohara, T.; Sudo, K.; Itsubo, N. Development of human health damage factors for tropospheric ozone considering transboundary transport on a global scale. Int. J. Life Cycle Assess. 2018, 23, 2339-2348. [CrossRef]

53. Motoshita, M.; Ono, Y.; Pfister, S.; Boulay, A.; Berger, M.; Nansai, K.; Tahara, K.; Itsubo, N.; Inaba, A. Consistent characterisation factors at midpoint and endpoint relevant to agricultural water scarcity arising from freshwater consumption. Int. J. Life Cycle Assess. 2018, 23, 2276-2287. [CrossRef]

54. Yamaguchi, K.; Ii, R.; Itsubo, N. Ecosystem damage assessment of land transformation using species loss. Int. J. Life Cycle Assess. 2018, 23, 2327-2338. [CrossRef]

55. Available online: https://www.europarl.europa.eu/RegData/etudes/BRIE/2019/631047/IPOL_BRI(2019) 631047_EN.pdf (accessed on 5 March 2020).

56. IEA (International Energy Agency). World Energy Statistics and Balances; IEA Publications: Paris, France, 2017.

57. Ahmad, Y.J.; El Serafy, S.; Lutz, E. Environmental Accounting for Sustainable Development; The World Bank: Washington, DC, USA, 1989. 
58. U.S Energy Information Administration, International Energy Statistics 2019. Available online: https: //www.eia.gov/beta/international/data/browser/ (accessed on 12 November 2019).

59. Carbon Brief, Mapped: The Global Coal Trade 2016. Available online: https://www.carbonbrief.org/mappedthe-global-coal-trade (accessed on 4 November 2019).

60. International Energy Agency (IEA). World Energy Prices 2019; IEA Publications: Paris, France, 2019.

61. European Environment Agency, 2008. Efficiency of Conventional Thermal Electricity and Heat Production in Europe. 2008. Available online: https://www.eea.europa.eu/data-and-maps/indicators/efficiency-ofconventional-thermal-electricity-generation-4/assessment-2 (accessed on 4 November 2019).

62. Young, B.; Krynock, M.; Carlson, D.; Hawkins, T.R.; Marriott, J.; Morelli, B.; Jamieson, M.; Cooney, G.; Skone, T.J. Comparative environmental life cycle assessment of carbon capture for petroleum refining, ammonia production, and thermoelectric power generation in the United States. Int. J. Greenh. Gas Control 2019, 91, 102821. [CrossRef]

63. Yu, P.; Luo, Z.; Wang, Q.; Fang, M. Life cycle assessment of transformation from a sub-critical power plant into a polygeneration plant. Energy Convers. Manag. 2019, 198, 111801. [CrossRef]

64. Tarannum, I.; Mohammedy, F.M. Life Cycle Assessment of Natural Gas and Heavy Fuel Oil Power Plants in Bangladesh. In Proceedings of the TENCON 2019-2019 IEEE Region 10 Conference (TENCON), Kochi, India, 17-20 October 2019.

65. Xie, J.; Fu, J.; Liu, S.; Hwang, W. Assessments of carbon footprint and energy analysis of three wind farms. J. Clean. Prod. 2020, 254, 120159. [CrossRef]

66. Kouloumpis, V.; Sobolewski, R.A.; Yan, X. Performance and life cycle assessment of a small scale vertical axis wind turbine. J. Clean. Prod. 2020, 247, 119520. [CrossRef]

67. Besseau, R.; Sacchi, R.; Blanc, I.; Pérez-López, P. Past, present and future environmental footprint of the Danish wind turbine fleet with LCA_WIND_DK, an online interactive platform. Renew. Sustain. Energy Rev. 2019, 108, 274-288. [CrossRef]

68. Parisi, M.; Maranghi, S.; Vesce, L.; Sinicropi, A.; Di Carlo, A.; Basosi, R. +Prospective life cycle assessment of third-generation photovoltaics at the pre-industrial scale: A long-term scenario approach. Renew. Sustain. Energy Rev. 2020, 121, 109703. [CrossRef]

69. Liu, F.; van den Bergh, J.C. Differences in $\mathrm{CO}_{2}$ emissions of solar PV production among technologies and regions: Application to China, EU and USA. Energy Policy 2020, 111234. [CrossRef]

70. Mérida García, A.; Gallagher, J.; McNabola, A.; Camacho Poyato, E.; Montesinos Barrios, P.; Rodríguez Díaz, J. Comparing the environmental and economic impacts of on- or off-grid solar photovoltaics with traditional energy sources for rural irrigation systems. Renew. Energy 2019, 140, 895-904. [CrossRef]

71. Zang, G.; Zhang, J.; Jia, J.; Lora, E.S.; Ratner, A. Life cycle assessment of power-generation systems based on biomass integrated gasification combined cycles. Renew. Energy 2020, 149, 336-346. [CrossRef]

72. Masum, M.F.H.; Dwivedi, P.; Anderson, W.F. Estimating unit production cost, carbon intensity, and carbon abatement cost of electricity generation from bioenergy feedstocks in Georgia, United States. Renew. Sustain. Energy Rev. 2020, 117, 109514. [CrossRef]

73. Sanchez Moore, C.C.; Anton, L.; Cardoso, F.H.; Kulay, L. Effect of Process Parameters on Bioelectricity Production, Energy and Environmental Performance. J. Sustain. Dev. Energy Water Environ. Syst. 2019, 7, 567-583. [CrossRef]

74. Yan, L.; Cao, Y.; He, B. Energy, exergy and economic analyses of a novel biomass fueled power plant with carbon capture and sequestration. Sci. Total Environ. 2019, 690, 812-820. [CrossRef]

75. Paulillo, A.; Cotton, L.; Law, R.; Striolo, A.; Lettieri, P. Geothermal energy in the UK: The life-cycle environmental impacts of electricity production from the United Downs Deep Geothermal Power project. J. Clean. Prod. 2020, 249, 119410. [CrossRef]

76. Karlsdottir, M.R.; Heinonen, J.; Palsson, H.; Palsson, O.P. Life cycle assessment of a geothermal combined heat and power plant based on high temperature utilization. Geothermics 2020, 84, 101727. [CrossRef]

77. Paulillo, A.; Striolo, A.; Lettieri, P. The environmental impacts and the carbon intensity of geothermal energy: A case study on the Hellisheiði plant. Environ. Int. 2019, 133, 105226. [CrossRef]

78. Yuguda, T.K.; Li, Y.; Xiong, W.; Zhang, W. Life cycle assessment of options for retrofitting an existing dam to generate hydro-electricity. Int. J. Life Cycle Assess. 2020, 25, 57-72. [CrossRef] 
79. Ueda, T.; Roberts, E.S.; Norton, A.; Styles, D.; Williams, A.P.; Ramos, H.M.; Gallagher, J. A life cycle assessment of the construction phase of eleven micro-hydropower installations in the UK. J. Clean. Prod. 2019, 218, 1-9. [CrossRef]

80. Mahmud, M.A.P.; Huda, N.; Farjana, S.H.; Lang, C. A strategic impact assessment of hydropower plants in alpine and non-alpine areas of Europe. Appl. Energy 2019, 250, 198-214. [CrossRef]

81. Kaddoura, M.; Tivander, J.; Molander, S. Life Cycle Assessment of Electricity Generation from an Array of Subsea Tidal Kite Prototypes. Energies 2020, 13, 456. [CrossRef]

(C) 2020 by the authors. Licensee MDPI, Basel, Switzerland. This article is an open access article distributed under the terms and conditions of the Creative Commons Attribution (CC BY) license (http://creativecommons.org/licenses/by/4.0/). 